\title{
Never Say Never: Commentary on a Policymaker's Reflections
}

\author{
Maurice Obstfeld*
}

December 14, 2013

\begin{abstract}
$\underline{\text { Abstract }}$
Stanley Fischer is a rarity among economic policymakers. He came to the policy world as an internationally recognized intellectual leader on macroeconomic theory and policy. $\mathrm{He}$ confronted numerous emerging market crises, including the globally systemic Asian crisis, as the IMF's First Deputy Managing Director from September 1994 to August 2001. And then, as governor of an emerging economy's central bank starting in May 2005 , he decided the monetary responses to the worldwide crisis of 2008-09 and its aftershocks. Fischer's unpublished Robbins Lectures, delivered at the LSE late in 2001, drew lessons from his service at the IMF. Did emerging markets follow up on those lessons, and did their preparations help them weather the storm of 2008-09? How have economists' views, and Fischer's, changed as a result of the global financial crisis? In this paper I propose answers to these questions, focusing on the experiences of three Asian crisis countries, Indonesia, Korea, and Thailand.
\end{abstract}

\footnotetext{
*University of California, Berkeley; CEPR; and NBER. I am grateful for comments from Pierre-Olivier Gourinchas, Harold Obstfeld, Carmen Reinhart, three anonymous referees, seminar participants at Victoria University and the Reserve Bank of New Zealand, and participants at the IMF's $14^{\text {th }}$ Jacques Polak Annual Research Conference (especially Stanley Fischer). Sandile Hlatshwayo provided expert and dedicated research assistance. The Center for Equitable Growth and the Coleman Fung Risk Management Research Center at UC Berkeley supplied essential financial support.
} 


\section{Introduction}

In his Robbins Lectures delivered at the London School of Economics in October 2001, Stanley Fischer distilled lessons from his years on the front lines of financial crisis management at the International Monetary Fund.

To my knowledge, the lectures have not been published in full; they reside only at www.stanleyfischer.com in the form of a single-spaced typescript of 89 pages (see Fischer 2001a). This is socially inefficient (but thank goodness for the Internet). The lectures offer not only a leading policymaker's perspective on six major emerging market crises of the 1990s, they also deduce a number of highly informed hypotheses as to what works and does not work in avoiding and managing financial crises. ${ }^{1}$

The website's link to Stan's Robbins Lectures is followed by the words "under revision, comments welcome.” Admittedly, the comments I will offer in this paper are unreasonably belated. My excuse for offering them on this occasion is, however, persuasive. The global economic turbulence that began in 2007 has given us another chance to observe Stan's crisis economies under stress. And while much of the industrial world remains mired in economic slowdown as a result of the global crisis, emerging markets in most of the regions that seemed most vulnerable during Stan's tenure at the Fund have generally suffered less than in past crises and returned quickly to relatively healthy growth. As it turns out, many of these countries used the relative calm of the inter-crisis period to reform their policy frameworks (and in some cases political institutions) in pursuit of improved economic performance and resilience. Therefore, we

\footnotetext{
${ }^{1}$ See Fischer (2001a). A portion of these unpublished lectures, suitably updated, has been published as Fischer (2003a).
} 
are now in a good position to begin to reassess Stan's recommendations in the light of subsequent data. ${ }^{2}$

Four questions naturally occur as one reads Stan's lectures more than a decade after their composition:

- To what extent did emerging countries follow the Fischer prescriptions of 2001 as they prepared for possible future crises?

- Were these measures effective?

- What other policy initiatives were helpful?

- What have we learned as a result of the global crisis that would lead us to supplement or qualify Stan's earlier recommendations?

In this paper I will offer some answers, answers that naturally - in the pragmatic, non-ideological spirit exemplified by Stan's own writings - are subject to amendment in light of future events and investigation. More than at any time since the 1930s, macro and finance economists' beliefs about the world should be "under revision, comments welcome."

Some preliminary disclaimers are necessary. My treatment will not be statistically rigorous, though I will draw on a subset of the copious statistical studies that others (many of them at the Fund) have carried out in recent years. In addition, I will not cover all six of the countries discussed by Stan in his lectures, but will focus on three of the

\footnotetext{
${ }^{2}$ There is now a significant body of research on emerging and developing economies' relative resilience in the global financial crisis (including discussion of differences across countries). This paper cannot possibly cover the relevant ground in detail. For surveys, see Kose and Prasad (2010), Gourinchas and Obstfeld (2012), Didier, Hevia, and Schmukler (2012), and Ceballos, Didier, Hevia, and Schmukler (2013).
} 
Asian countries hit hardest in the turmoil of 1997-98: Indonesia, Korea, and Thailand. The heavy banking-related losses that these countries sustained in their 1997-98 crises qualifies them (along with Mexico 1994-95) as twenty-first century crises, in the phrase of Michel Camdessus. We have now had two decades of twenty-first century crises, which have spread to encompass advanced countries, including several in the euro area. To foreshadow my conclusions, I will largely endorse Stan's positions as of 2001, but also argue that subsequent events, while generally strengthening Stan's previous arguments, have added important new twists and challenges. As I will describe, Stan's eight years as governor of the Bank of Israel (starting in May 2005) illustrate the evolution of his thinking - and that of economists more broadly - as he migrated from the IMF side to the emerging-market side of crisis management. ${ }^{3}$

\section{Six Crises: Contrast in Outcomes between 1997-98 and 2008-09}

The Asian crisis of 1997-98 began in Thailand in mid-1997 and spread contagiously throughout Asia, in particular to Korea and Indonesia, both of which turned to the International Monetary Fund for support. Weighing down these countries were the weak Japanese currency and economy, but not a global trade collapse and financial-market convulsion, as occurred in 2008-09. On the other hand, China's remarkable growth in the decade following the Asian crisis had reshaped regional trade relationships. The Chinese economy's resilience and countercyclical fiscal response in 2008-09 was a partial offset to the sharp fall in worldwide economic activity, as were sharp interest-rate cuts in the industrialized world.

\footnotetext{
${ }^{3}$ Consistent with his unique perspective, Stan has written and spoken insightfully on the lessons of very recent experience, as I will note frequently in context below.
} 
An abstract of the 1997-98 Asian crisis, however brief and impressionistic, is a useful background for the discussion below. ${ }^{4}$ The Asian crisis was notable in that, outside of Thailand, most of the countries it directly hit showed few ex ante signs of conventional macroeconomic imbalances such as obviously overvalued real exchange rates or big government deficits. The notable features they did share were rigid (de jure or de facto) nominal exchange rates and fragile financial systems with big dollar liabilities, distorted by connected lending practices and implicit expectations of some form of government bailout in the event of a crisis. Thailand most obviously exhibited conventional overheating symptoms of credit boom, excessive investment, and high current account deficit, symptoms that indeed elicited unheeded warnings from the IMF prior to 1997 . Once the boom came to an end in that country and asset prices declined, the baht, long fixed to the US dollar, came under attack. The Thai authorities ran their reserves down in a vain defense, prior to floating the currency for the first time in 14 years on July 2, 1997.

But then the crisis spread contagiously to other Asian countries, bringing down economies that seemed superficially better positioned to resist. In reality, they harbored critical financial vulnerabilities. It came as a surprise to many observers that these vulnerabilities, in and of themselves, could furnish the entry pathway for the crisis virus. ${ }^{5}$

\footnotetext{
${ }^{4}$ For recent overviews of crisis experience and theory, see Montiel (2013), Claessens, Kose, Laeven, and Valencia (2014), and Goldstein and Razin (2014).

${ }^{5}$ Just prior to the Asian events, Dornbusch (1997, p. 383) summarized a widespread view holding that some macro misalignment is a necessary condition for a crisis: "Financial considerations are all important in interpreting specific events, but must not be misconstrued as the primary or sole source of a collapse." Those who closely followed the Asian economies, including economists in the Fund, certainly had worries about financial excesses (notably in Indonesia), yet the prevailing wisdom at the time was that good macro fundamentals overall made crises unlikely despite sometimes substantial borrowing from abroad. For example, in their insightful work on the "overborrowing syndrome," McKinnon and Pill (1997, p. 189) wrote: "[N]ot all liberalizing countries attracting large capital inflows need experience [a] boom-and-bust cycle. Indonesia, Malaysia, and Thailand have all had current-account deficits of 5-8 percent of GNP (similar to Mexico before the fall) for almost a decade, without a Mexico- or Chile-type debacle. These
} 
Even earlier doubters such as Krugman (1999) became convinced that these contagious attacks were initially of a self-fulfilling nature, inspired by investor beliefs that other Asian countries' financial systems had weaknesses similar to Thailand's and therefore would crater under a forced currency depreciation. Like Thailand, Korea and Indonesia's banks and corporations had substantial short-term debts denominated in foreign currency. A "sudden stop" in gross capital inflows, including refusal to roll over maturing short term credits, implied not only a severe external funding gap, but steep currency depreciation that rendered many financial actors insolvent. Conversely, currency speculation leading to exhaustion of government resolve and currency depreciation would wreck balance sheets, making widespread insolvency likely and therefore inspiring a lenders' strike. Once the dual currency and creditor runs hit, the economic and political dynamics played out differently in the affected countries, worst of all in Indonesia.

Some critics of the IMF's rescue programs argued that, since the attacks reflected self-fulfilling panic, the proper response in countries such as Indonesia and Korea would have been much more generous liquidity provision, without the financial reform programs the Fund in fact imposed as a central part of its conditionality. Without endorsing every element of Fund intervention - and Stan himself as well as studies out of the Fund such as Boorman et al. (2000) admit mistakes - I personally agree with Stan and find this view naïve. Once a large-scale attack occurs and makes potential financial weaknesses manifest to all, then even if the attack has its origins in self-fulfilling expectations, there will in practice be no way to put the genie back into the bottle without

East Asian economies achieved virtual steady-state growth with high saving and very high investment, although doubts about its quality could yet provoke a cutback in foreign lending." 
repair of the underlying sources of vulnerability. Confidence, at that point, is irreparably damaged. In analogy, in the euro zone today, few believe that even unlimited ECB support of sovereign debt markets would do much more than buy time for more fundamental reforms. And in Asia in the late 1990s, the official resources on the table were far more limited than those of the ECB.

In 2008-09 Asian countries were hit from abroad by a historic convulsion in global goods and asset markets, and they faced both sharply reduced export demand and global financial retrenchment. Nonetheless, the Asian economies all performed far better in the global economic crisis than they had a decade earlier. ${ }^{6}$ Figure 1 illustrates the contrasting behavior of output for Thailand, Korea, and Indonesia around the Asian crises (1997-98) and the global economic crisis (2008-09). (In the figures, year $t$ for the Asian crisis is 1998, whereas year $t$ for the global crisis is 2009.) In all three countries, output growth was somewhat stronger before the Asian crisis, reflecting domestic booms, but the crash in output is much bigger. Reflecting high pre-crisis demand and its huge compression as a result of the Asian crisis were the sharp turnarounds from deficit to surplus in all three countries' current accounts. In 2009, in contrast, the increase in current account balances (which were in surplus or balanced before the crisis) was much smaller (Figure 2). Finally, Figure 3 shows that investment rates were higher before the Asian crisis and then crashed dramatically, while investment falls mildly, if at all, in the more recent crisis. Before the Asian crisis, high investment levels were driven in part by domestic lending booms, particularly in Thailand, a factor that contributed to the other countries' vulnerability to expectational contagion.

\footnotetext{
${ }^{6}$ Goldstein and Xie (2010) ventured an early assessment of the extent of Asian resilience. Later events justified the guarded optimism they expressed, and many of the points I make below echo their reasoning.
} 
Although external circumstances differed as between the two time periods, with significant effects on outcomes, Thailand, Korea, and Indonesia all instituted major changes in their economic policies and their policy frameworks as a result of the Asian crisis. As I document below, along many of the dimensions economic research has identified as relevant, the three Asian economies were all more robustly defended against crisis outcomes in the late 2000s than a decade before.

In his Robbins Lectures Stan Fischer identified key macroeconomic factors in crisis prevention and mitigation. To what extent were these important in generating the more favorable outcomes in 2008-09, and what other factors were in play? I now turn to a discussion of Fischer's views as of 2001 and their applicability to the Asian economies' recent experiences.

\section{Lessons of the Asian Crisis}

Fischer (2001a) identified six key areas in which improved policies and policy reforms would be critical for preventing future crises. These were:

- The exchange-rate system and the nominal anchor.

- Reserve management.

- Debt management.

- Capital controls.

- Oversight of the financial sector.

- Codes, standards, and transparency.

What measures did Stan recommend and to what degree did reforms over the decade 1998-2007 enable the three Asian countries to withstand the force of the subsequent 
global tsunami? I will group the preceding policy areas into three categories and discuss each in turn.

The exchange-rate system and the nominal anchor. This topic is so fundamental and extensive that it deserves a sub-section of its own. Prior to the Asian crisis of 199798, Thailand, Korea, and Indonesia had informal exchange rate pegs - quite tight in the cases of Thailand and Indonesia, less so in the case of Korea - but understood by markets to imply definite lines of defense by the respective monetary authorities. These pegs also furnished the main nominal anchors in the three economies. Subsequently, all three countries moved to managed floats. Fischer (2001a) believed that "of all the changes in the international financial system that have taken place since 1994, the shift towards flexible exchange rates by emerging market countries is the one that has most reduced the risk of future crises.” This judgment reflected Fischer's (2001b) “bipolar” view of exchange rate regimes: given the monetary policy trilemma for open economies, intermediate exchange rate systems where authorities draw a line in the sand and are seen to be trying to defend a particular rate will eventually succumb to speculative attack. ${ }^{7}$

Fischer's conclusion raised two main questions. First, what should replace the exchange rate as a nominal anchor? And second, if tight management of the exchange rate is ruled out, how should authorities deal with currency fluctuations that might be undesirable, particularly for emerging markets?

Except for countries struggling with very high inflation rates (say 40 percent per year and over), Fischer recommended inflation targeting, probably less formal than "Bank of England standards," possibly supplemented by monetary targets in cases where

\footnotetext{
${ }^{7}$ One might well ask, in light of the collapse of Argentina's convertibility plan, and, even more dramatically, speculation against euro zone "irrevocable" parities, what remains of the "hard peg" pole.
} 
inflation exceeds the 20-25 percent range. The three Asian countries, with IMF encouragement, all introduced inflation targeting and central bank operational independence after the Asian crisis. Korea initially introduced inflation targeting in April 1998, Indonesia in January 2000, and Thailand in May 2000. ${ }^{8}$ Regarding the complementary institutional reforms, Korea passed the Bank of Korea Act 2003 for this purpose; Indonesia in 1999 passed a new central bank law to give Bank Indonesia independence in pursuit of stable prices; and the Bank of Thailand, under authority of the 1942 Bank of Thailand Act, established a Monetary Policy Board (April 2000), soon replacing it by a de facto independent Monetary Policy Committee (July 2001). All three countries now publish inflation or monetary policy reports. ${ }^{9}$

Figure 4 shows how realized headline year-average CPI inflation rates compare to announced target ranges (leaving aside that some of the countries, at some times, have targeted core rather than headline inflation). ${ }^{10}$ For Korea and Thailand the record is fairly strong. Indonesia does reasonably well after its move to formal inflation targeting in 2005 , except for 2008, a year of high food and energy price inflation, and again very recently. Possibly, inflation expectations have been less firmly anchored in Indonesia than in Korea and Thailand.

That would not be surprising given Indonesia's inflation experience during the Asian crisis (and before). Figure 5 compares the inflation performance in the Asian crisis with that in the Great Recession. In Indonesia, the rupiah collapsed decisively starting in late 1997 as the banking system went into crisis and Bank Indonesia pumped liquidity

\footnotetext{
${ }^{8}$ Indonesia formally introduced its inflation targeting framework in July 2005. It first announced an explicit inflation target in January 2000.

${ }^{9}$ For more discussion, see Ito and Hayashi (2004), which focuses on Asia, and Hammond (2012).
} 
into the economy. Based on year-average CPI differences, the 1998 inflation rate was 78 percent, having been above 10 percent in 1997. Inflation rose in Korea and Thailand in 1997, but only moderately, and it then declined. On the whole, inflation remained more stable in all three countries than it did around the Asian crisis. The maintenance of a constant nominal anchor probably deserves part of the credit, especially because the global crisis was accompanied by substantial nominal depreciation - albeit not as dramatic as in the Asian crisis - in Korea and Indonesia (see Figure 6). Better-anchored inflation expectations provided an environment in which Asian monetary authorities could cut policy interest rates countercyclically, rather than raising them (or allowing them to rise) as in 1997-98 (Figure 7). ${ }^{11}$

Nonetheless, an unresolved issue is the importance of the inflation targeting framework per se to these outcomes. Asian non-inflation targeters, such as Malaysia, also had good inflation performance despite the recent crisis. In contrast, not only Indonesia but also the inflation-targeting Philippines have done worse. In their comprehensive assessment of Thailand's monetary policy, Grenville and Ito (2010, p. 93) judiciously conclude that "the good performance of Thailand should not be attributed solely to the inflation targeting framework but to the broader acceptance in the government and the community that price stability is worthwhile." Perhaps a dose of Stabilität Kultur is a helpful complement to an inflation target.

\footnotetext{
${ }^{10}$ In Figure 4 and in Figure 5 below, inflation is measured as the percent change in the year-average CPI.

${ }^{11}$ Using a sample of 51 advanced and emerging economies, de Carvalho Filho (2011) documents the relatively favorable performance of the inflation targeting countries in the face of the global crisis. See also De Gregorio and Alvarez (2014). Gertler, Gilchrist, and Natalucci (2007) present a theoretical New Keynesian model inspired by Korea's Asian crisis experience. They show why a floating exchange rate, allowing a countercyclical monetary response, can dominate a fixed rate in an external funding crisis, even in the presence of some liability dollarization. Consistent with the previous paper's theoretical approach, Elekdag, Justiniano, and Tchakarov (2006) estimate a dynamic sticky-price model using Korean data and find strong empirical support for a financial accelerator mechanism driven by balance-sheet effects.
} 
Figure 6 also illustrates other patterns in exchange rate behavior around the two crises. The three countries abandoned their pegs in the Asian crisis and have since then refrained from defending explicit exchange rate targets. Despite this change, nominal exchange rates have been somewhat more variable after the Asian crisis, but not extremely variable in general, and they have exhibited a fair amount of longer-term stability. Figure 8 underscores the before/after comparison of short-term volatility: it graphs against time monthly data for the within-month standard deviation of the log nominal bilateral US dollar exchange rate. In the global crisis, nominal exchange rates were allowed to depreciate, most dramatically the rupiah and the won, which dropped sharply to absorb the shock of net capital outflows (Figure 6). The baht and the rupiah soon returned close to pre-crisis levels, whereas Korea, which suffered the most severe financial-market reversal of the three countries, let its currency depreciate more persistently.

The recent seeming stability of these currencies apart from crises, even though their exchange rates are flexible, is reminiscent of the "fear of floating" phenomenon that Calvo and Reinhart (2002) documented shortly after the Asian crisis for a broad set of emerging and developing economies. In the past decade, EME exchange rates have tended to be more volatile than in the data Calvo and Reinhart analyzed, of course, but in tranquil times volatility has been moderate. Have the three Asian countries found a way to violate the monetary trilemma, stabilizing nominal exchange rates despite reasonably open capital markets and a monetary policy directed at domestic goals? ${ }^{12}$

\footnotetext{
${ }^{12}$ If one simply looks at the variances of exchange-rate changes, one may see little difference between emerging and advanced economies in many cases. Where there does seem to be a noticeable difference is in the overall character of the exchange-rate change distribution: for EMEs, weight is often pushed out to the tails, indicating less variability most of the time but more frequent large changes in exceptional
} 
Fischer (2001a) observes that "monetary policy in (emerging) countries with floating exchange rate systems is likely to respond to movements of the exchange rate."13 The central importance of the exchange rate for such open economies - due to dollarized liabilities, high pass-through, allocational frictions, and so on -- makes this inevitable. But such monetary-policy responses, if systematic, are not obviously compatible with price-level stability. It could be, on the other hand, that policymakers in our Asian countries (all three of them!) actually desired exchange rates far different from those produced under their inflation-targeting regimes, yet have been reluctantly forced by markets to accept stable currency values. Merely stating this hypothesis reveals how farfetched it is: it is more fruitful to ask what aspects of emerging market policies, collateral or purposeful, have produced a degree of exchange stability.

Most obviously, given the relatively high openness and exchange-rate passthrough for these economies, a key element in stabilizing CPI inflation (even core CPI inflation) is exchange-rate stability (given the prevalence of fairly low rates of inflation in trading partners). In addition, even a perceived narrow range of normal exchange-rate

circumstances, such as crises. A crude way of getting at this phenomenon is to calculate kurtosis (which, for a normal distribution, is equal to 3). Consider the following summary statistics for the distributions of end-month $\log$ exchange rate changes against the U.S. dollar, January 2000-September 2013:

\begin{tabular}{|l|r|r|}
\hline Country & \multicolumn{1}{|l|}{ Kurtosis } & \multicolumn{1}{l|}{ Std dev } \\
\hline Korea & 7.64 & 0.034 \\
\hline Indonesia & 8.53 & 0.036 \\
\hline Thailand & 4.90 & 0.020 \\
\hline Euro & 4.03 & 0.031 \\
\hline Japan & 3.19 & 0.028 \\
\hline UK & 4.87 & 0.026 \\
\hline Australia & 5.10 & 0.040 \\
\hline
\end{tabular}

The three Asian currencies generally display higher kurtosis relative to the industrial comparators, with the possible exception of Thailand, which, however, shows the lowest overall currency variability. As in my calculation, Calvo and Reinhart (2000) essentially looked at the probability mass in distributions' tails. ${ }^{13}$ Eichengreen (2004) soon confirmed this for the Bank of Korea's post-Asian crisis interest-rate rule. Edwards (2007), Stone et al. (2009), and Ostry, Ghosh, and Chamon (2012) discuss other evidence. 
fluctuation can allow huge international differences in policy interest rates (Obstfeld, Shambaugh, and Taylor 2005). Central banks could easily follow conventional-looking Taylor rules, although they would likely include a strong response to the exchange rate because of its relation to domestic inflation. Thus, Fischer (2001a) notes that the exchange rate interacts with pricing behavior, so that open-economy inflation targeters automatically need to take the exchange rate into account in setting monetary policy.

The likely performance of alternative policy rules in emerging economies is the subject of ongoing research, but I feel certain (and theory also suggests) that a "divine coincidence" between inflation targeting and exchange rate stabilization -- especially when inflation targeting is "flexible" so as to promote stability of output -- is too much to hope for in general, even during tranquil times in international markets. The exchange rate is driven by a multitude of potential shocks - to capital flows, foreign demand and monetary conditions, the terms of trade and commodity prices, to name a few - and in principle these disturbances interact differently with domestic inflation. An appreciation driven by a rise in foreign investors' confidence in the currency (perhaps manifested in carry-trade inflows) could be deflationary, prompting a cut in the interest rate. In this case, the central bank response is stabilizing for the exchange rate. But this is not always the case. For a commodity exporter, favorable terms of trade are inflationary other things equal, and they therefore prompt a rise in the policy interest rate as the currency strengthens. In this case, monetary policy amplifies the exchange rate movement rather than dampening it. Optimal responses depend on the nature of the shock, and if the policymaker doesn't observe the shock and must extract a signal based on an analysis of 
historical data, then the response will reflect estimated variance ratios, supplemented by whatever useful current information may be available. ${ }^{14}$

Supplementing any smoothing response of interest rates to exchange rates is direct intervention in foreign exchange markets. Intervention, typically sterilized, has been practiced on a much larger scale in emerging than in advanced economies (as also pointed out by Calvo and Reinhart 2002). On a strict reading of the monetary trilemma, this is puzzling: with monetary policy targeting inflation, it cannot also be directed toward the exchange rate, and sterilized interventions will not affect the exchange rate. But for emerging markets, policy practice makes sense only under the hypothesis that the strict trilemma does not bite in the short term, and perhaps not even over the medium term. Unfortunately, the direct empirical evidence on the question is somewhat sparse and not entirely unanimous, as discussed by Ostry, Ghosh, and Chamon (2012). ${ }^{15}$

In the Robbins Lectures, Fischer (2001a) endorses the utility of interventions "from time to time," provided authorities "are not perceived as trying to defend a particular exchange rate." (Italics in original.) But the 2001 lectures contain no endorsement of intervention as a regular, systematic part of the policy mix. Indeed, for

\footnotetext{
${ }^{14}$ Some monetary policy studies based on estimated models of the Korean economy suggest a limited role for the exchange rate, per se, in the optimal interest rate rule. The analyses thus support a pure inflation targeting approach. See, for example, Chung, Jung, and Yang (2007) and Sánchez (2009). However, these papers do not allow the possibility of sterilized foreign exchange intervention, which I take up next; the welfare criteria they assume omit variables that could be important policy targets in EMEs; and they do not explicitly include a balance-sheet channel -- which, as noted above, is empirically important.

Of course, there is also the important question of which price index to target. Frankel (2010), for example, argues that because supply shocks and terms of trade shocks are particularly important for emerging economies, responsiveness to the headline CPI could exacerbate output volatility. Use of the core CPI instead would reduce the problem. In contrast, De Gregorio (2012) presents a case for some responsiveness of monetary policy to commodity-price shocks, especially food-price shocks, and especially in the EME context. Bodenstein, Guerrieri, and Kilian (2012) and Monacelli (2013) offer alternative recent theoretical analyses in open-economy models with commodity price shocks. Monacelli in particular stresses the breakdown of the different but related "divine coincidence" of Blanchard and Galí (2007).

${ }^{15}$ For another survey, including a somewhat negative assessment of the Czech National Bank's interventions against the euro in 2001-02, see Disyatat and Galati (2007). See also Frankel (2010). Kamil
} 
nearly three years after Stan's arrival on May 1, 2005, the Bank of Israel under his

leadership continued a policy of nonintervention in the foreign exchange market to which

it had adhered since 1997. ${ }^{16}$ However, in March 2008 (coincident with the Bear Stearns

run and takeover), the BOI entered the foreign exchange market as a buyer of foreign

exchange and it has continued to intervene ever since as circumstances dictate. ${ }^{17}$

Figure 9 shows the evolution of Israel's U.S. dollar exchange rate and foreign

exchange reserves after this policy shift. By September 2009 the shekel had stopped

appreciating and had returned almost to its March 2008 level. Although the shekel then

depreciated sharply in the immediate wake of the Lehman collapse, the BOI continued to

buy reserves at a rapid pace. In March 2009, the direction of currency pressure shifted as

the negative shock to emerging markets receded. Faced with highly accommodative

(2008) is a recent case study of Colombia. For evidence on the increasing use of sterilized intervention in emerging markets, see Aizenman and Glick (2009), Stone et al. (2009), and Mehrotra (2012).

${ }^{16}$ Fischer (2008, p. 370) explained the rationale for this policy as follows: "In the case of Israel, where there are essentially no capital controls, the nonintervention policy is based on the view that intervention is unlikely to have a sustained effect on the exchange rate, and that monetary policy decisions are more fundamental. Further, the central bank believes that the foreign exchange market works better when market participants do not expect the central bank to intervene except in extreme circumstances, and thus have to focus in their decisions on the underlying forces that determine the exchange rate." However, policies changed as circumstances changed.

${ }^{17}$ Intervention was prompted by several circumstances alongside the global unease about U.S. financial stability, including domestic and global macro developments and a sense that in a more volatile global economy, Israel's foreign exchange reserves should be higher. As Fischer put it in his transmission letter accompanying the Bank of Israel's Inflation Report for the first quarter of 2008 (at http://www.boi.org.il/en/newsandpublications/regularpublications/pages/eng_inf0801e.aspx):

In March the Bank of Israel intervened in the foreign exchange market for the first time in eleven years: on 13 and 14 March, against the background of abnormal movements in the shekel exchange rate in the previous few days, the Bank purchased about $\$ 600$ million of foreign currency on the market.

At about the same time, on 20 March, the Bank started implementing a program to increase the level of the foreign exchange reserves by about $\$ 10$ billion in the next two years, by buying about $\$ 25$ million a day on the market. This is a small amount compared to the average daily volume of trade in the market, about $\$ 2$ billion, although the cumulative annual purchases are not small. The program, which had been drawn up in the course of the previous few months, is intended to adjust the level of Israel's foreign exchange reserves to the levels customary in comparable economies, against the background of Israel's rapid economic growth and its increasing integration into the global economy. 
monetary policies in the major industrial countries, many emerging economies, Israel among them, tolerated currency appreciation as their policymakers began to worry about domestic overheating. The pace of reserve purchases has reflected these pressures. Since the BOI intervention policy was initiated in March 2008, Israel's foreign reserves have risen from just under $\$ 30$ billion to almost $\$ 80$ billion. Over Fischer's entire tenure as governor, reserves tripled.

Stan's current view, as expressed in Fischer (2013), is that central banks can successfully intervene, at least to resist appreciation pressures, and that in such cases, the resulting foreign exchange inflows can be sterilized to neutralize their inflationary impact, "as the Bank of Israel and other central banks have shown over the last three years." Stan elaborates as follows:

Central bankers used to say that they have only one instrument - the interest rate and thus can have only one target - the inflation rate. That view, which is based on the Tinbergen result that there should be as many instruments as there are goals of policy, is not generally correct .... But in any case, I see the instrument of intervention in the foreign exchange market as in effect giving the central bank an extra instrument (or at least an extra half-instrument) of policy, which enables it not only to target inflation but also to have some influence on the behavior of the exchange rate.

As Stan has repeatedly made clear, however, to "have some influence on the behavior" of the exchange rate is not to defend a specific target level or band through intervention, independently of the interest rate.

My interpretation of Stan's "half-instrument" remark is as follows: to resist a capital outflow and depreciation pressures, the central bank must supply foreign exchange to the market, and it cannot supply unlimited amounts. So in this case there is eventually instrument insufficiency. On the other hand, the case of capital inflows and appreciation pressures is asymmetric, because the central bank can supply unlimited 
domestic currency to cap its price (as the Swiss National Bank has been demonstrating of late). ${ }^{18}$ As Stan explains in Fischer (2010):

[T] he case of capital inflows ... is different. In that case, the central bank has the capacity to supply what the foreign exchange markets want - domestic currency. And provided the central bank is willing and able to sterilise the foreign exchange purchases, there need be no consequences for the inflation rate. The process can continue as long as the country is willing to continue to acquire reserves - and in recent years several countries have been willing to increase reserves by far more than anyone would have expected just a few years ago.

Hence, we have a "half-instrument": sterilized intervention works for capital inflows but not outflows, because the authorities can purchase reserves without limit and mop up the resulting liquidity, whereas they cannot automatically sell reserves without limit.

If I think back to the doctoral dissertation I wrote at MIT thirty-five years ago under the guidance of Professors Fischer and Dornbusch, this interpretation raises a question. When the central bank sterilizes a foreign exchange inflow by selling government bonds from its portfolio or issuing its own sterilization bonds, why does this not simply suck in an equal further foreign exchange inflow, completely negating the central bank's efforts to restrain monetary growth and inflation? The empirical study of such "offsetting capital flows" was initiated at the Fund by Kouri and Porter (1974) and Argy and Kouri (1974), inspired by the unsuccessful efforts Germany and Switzerland made toward the end of the Bretton Woods era to resist appreciation pressures while sterilizing extensively in pursuit of monetary control.

Let me be clear - the question is not about whether sterilized intervention will be painful as a result of quasi-fiscal costs, financial repression (such as higher reserve

\footnotetext{
${ }^{18}$ The Swiss case is special, however, in that Switzerland currently resides in a liquidity trap where even unsterilized purchases of foreign exchange will not influence inflation unless they are expected to swell the money supply permanently. Thus, the SNB does not face some factors that could normally limit the willingness to resist a prolonged inflow attack.
} 
requirements), or the like, although these side-effects would certainly reduce the authorities' incentives to resist appreciation forever. The question is about why, in light of the simplest Fleming-Mundell paradigm with full capital mobility, it even works. This takes us back to the possible mechanisms in play in the case of emerging markets, and the relevant empirical evidence.

The classic Kouri-Porter type of mechanism is imperfect substitutability between bonds denominated in different currencies. On this view, a sterilized purchase of foreign exchange, which raises the stock of home-currency bonds that the market must hold, leads to depreciation pressure, counteracting the appreciation pressure coming from foreign demand. Looked at another way, if foreigners want to swap foreign currency for domestic currency bonds because foreign interest rates fall, the central bank can accommodate this trade without altering the domestic interest rate by simply buying the foreign currency and supplying the bonds.

Another possibility is gradual portfolio adjustment, as modeled, for example, by Blanchard, Das, and Faruqee (2010) and Ostry, Ghosh, and Chamon (2012). (Of course, both imperfect substitution and imperfect mobility can, and do, coexist.) In this latter scenario however, the effects of sterilized intervention are likely to decay over time as capital gradually flows in, responding to interest differentials. Slow adjustment is likely to be especially relevant in the short run, given market thinness and other financial frictions in the EME setting, including various official restrictions on cross-border transactions. Some countries may find interventions more effective than others. Foreign exchange market depth and liquidity differ across emerging economies, which also differ in terms of their financial infrastructure and sophistication; their degree of integration 
with global markets; and the importance of their currencies in global transactions. Figure 10 , which compares currencies' shares in average daily global foreign exchange turnover to the issuers' global GDP shares, illustrates this heterogeneity for a range of mostly small and emerging economies. ${ }^{19}$

If the prime mechanism that gives sterilized intervention some traction is imperfect substitution, demand elasticities with respect to interest differentials are likely to be far lower in an environment of managed floating, where the short-run variability of the exchange rate (up or down) is substantial, than when authorities are defending a peg against attack and there is a one-way bet (the predicament of Germany and Switzerland forty years ago). This is another example of the benefits that follow from the Fischerian precept that the authorities should avoid drawing lines in the sand.

A final possibility follows from our limited understanding of money demand (and supply - what, exactly, is money?), of its interaction with bank activities, and of the latter's impact on output, prices, and the demand for transactions media. Lahiri and Végh (2003), for example, explore a model in which a class of nontraded domestic bonds yields money-like liquidity services, and this channel allows central bank operations to have some impact even if they do not affect the money supply sensu stricto. How does the economy react when the authorities require banks to hold central bank sterilization bonds rather than make loans? What is the effect of other forms of repression? Can intervention flows have a better chance of influencing the level of the exchange rate if they are sustained over time (like the Federal Reserve's current asset purchases)? Our understanding is limited, and there has been relatively little work modeling these issues

\footnotetext{
${ }^{19}$ Currency shares in turnover are taken from the BIS triennial April 2013 survey. GDP shares are for 2012 (in some cases IMF forecasts).
} 
with sufficient detail in the EME context. ${ }^{20}$ As I noted above, empirical studies of sterilization are comparatively small in number and coverage, they reach varied conclusions (for example, regarding levels versus volatility of exchange rates), and they throw little light on the structural features of asset markets that might allow pure intervention to be effective. Much more research is need before we have a firm understanding of whether, and how, sterilization affords EME policymakers with an extra degree (or even a half-degree) of freedom. ${ }^{21}$

Uncertainty about the effects of sterilized foreign exchange intervention parallels academic disagreement about the effects of unconventional monetary policies, recently implemented in several industrial economies as policy interest rates have approached or reached the zero lower bound. Sterilized intervention and unconventional monetary policy alike could work primarily through a signaling channel - because they convey information about future conventional monetary policy settings. But in this case, the credibility of the signals would influence their effectiveness, and, moreover, neither measure would truly be an independent policy tool, additional to conventional monetary policy.

Significant portfolio effects would, however, allow these policy levers to work independently of monetary policy. Central bank attempts to "twist" the term structure by

\footnotetext{
${ }^{20}$ A recent effort is Benes, Berg, Portillo, and Vavra (2013), who study the joint use of sterilized intervention and inflation-targeting monetary policy in an EME setting. The paper considers two separate rationales for effectiveness of sterilized intervention: an explicit portfolio diversification motive; and an assumption in the spirit of Lahiri and Végh (2003) that central bank nonmonetary liabilities and loans entail costs for the financial institutions that hold them, but with increasing marginal costs to holdings of either asset alone.

${ }^{21}$ In one recent study, Klein and Shambaugh (2013) find that even moderate exchange rate flexibility can afford lower-income countries some monetary autonomy, whereas limited and partial capital controls are less helpful. In contrast, Rey (2013) argues that even under a floating exchange rate, U.S. monetary and credit conditions are powerful (and perhaps overwhelmingly strong) determinants of domestic conditions, possibly making capital controls essential for monetary independence.
} 
selling short-maturity bonds and buying long-maturity bond are sterilized by design.

They potentially lower long-term interest rates relative to short rates through portfolio effects, as investors adjust to policy-induced imbalances (at the initial term structure) between investors' desired maturity mix and supply. Quantitative easing policies are not sterilized, but if they occur at the zero lower bound, their only effects will be portfolio effects unless markets believe that the monetary expansion that accompanies them signals persistently more accommodative future monetary policies. Are the portfolio effects alone significant? The evidence does not speak clearly. As in the case of sterilized foreign exchange intervention, central bankers seem to have more faith in the strength of portfolio effects than do academic researchers. $^{22}$

Pure foreign exchange intervention and unconventional monetary policies alike rely on failure of the Ricardian equivalence of public debt and taxes. If official balance sheets are internalized by the public via the government budget constraint, private investors might simply offset official central bank operations through shifts in their own asset demands, thereby deactivating the portfolio balance channel. ${ }^{23}$ Some studies of unconventional monetary policies assume that bonds provide direct liquidity services (similarly to Lahiri and Végh 2003), in which case Ricardian equivalence fails automatically because of the relative illiquidity of capitalized future tax and transfer streams. ${ }^{24}$ One might think of this device as a crude way to capture the government's ability to undertake some intermediation activities from which private agents, or at least

\footnotetext{
${ }^{22}$ See, for example, Bernanke, Reinhart, and Sack (2004) and Krishnamurthy and Vissing-Jorgensen (2011, 2013). If quantitative easing is ineffective at the zero lower bound, then in particular, it will not move the exchange rate. (For a textbook exposition, see Krugman, Obstfeld, and Melitz 2014, Chapter 17.) Using this criterion, few emerging-market policymakers would judge U.S. quantitative easing to be ineffective. ${ }^{23}$ For the case of foreign exchange intervention, I observed this in an old paper that was based on one of my dissertation chapters (Obstfeld 1980).
} 
some of them, are constrained, as in recent models of unconventional domestic monetary policy such as Gertler and Karadi (2011).

While sterilized intervention may be useful in dampening exchange-rate volatility, it is quite another matter to deploy it to slow longer-term trends - a corollary of Stan's injunction against drawing lines in the sand. This is another lesson of the recent experience of managed floating by EMEs. A central bank that persistently resists an appreciating currency trend, for example, sets up a dangerous dynamic in which expectations of further appreciation offer a virtual one-way bet to markets, encouraging further inflows and stronger upward pressure on the currency. Currency appreciation may loosen domestic collateral constraints, encouraging more borrowing from the demand side as well, while sterilization sales of domestic bonds drive up domestic-currency bond interest rates and reinforce the carry-trade dynamic. Quasi-fiscal costs also rise over time. The stage is then set for an ugly denouement when capital inflows reverse.

An important but under-emphasized point is that sterilization can be attempted not only through open-market mopping-up operations, but through changes in banks' reserve requirements (in effect, a tax intervention in the credit system). Somewhat out of favor in the advanced economies, this approach is more widespread in parts of the emerging world and may be making a comeback in connection with the macroprudential effects of liquidity requirements and domestic credit control. Theory and evidence suggest that higher reserve requirements at the same time lower banks' borrowing rates and raise their lending rates, making the measure particularly useful for responding to volatile capital flows. Consider an inflow surge to a booming emerging economy, the authorities of

\footnotetext{
${ }^{24}$ Examples of closed-economy models in which bonds yield direct liquidity services include Canzoneri, Cumby, Diba, and López-Salido (2008) and Krishnamurthy and Vissing-Jorgensen (2013).
} 
which intervene to resist appreciation. If the recipient central bank sterilizes its foreign exchange purchase by increasing required reserves, it will in effect also be tightening credit (by raising borrowing rates) while at the same time dampening appreciation (by lowering deposit rates). Provided it is not circumvented, the required reserve tax thus can help to decouple the exchange rate from domestic monetary policy. ${ }^{25}$

If sterilized foreign exchange intervention is not reliably effective as a tool independent of monetary policy, or is simply too painful to implement when practiced on a large scale, capital controls may come into play. I discuss that possibility shortly.

Management of reserves and debt. These topics naturally fit together as both relate to the structure of the national balance sheet and the ways in which its public and private subcomponents interact to influence both crisis vulnerability and crisis policy responses.

At several points, Fischer (2001a) asserts the folly of allowing official foreign exchange reserves to reach very low levels, as Thailand and Korea did during the Asian crisis; and he notes with approval Korea's achievement in rebuilding reserves to over $\$ 90$ billion in a short time. He endorses the view that a high ratio of reserves to short-term foreign liabilities can reduce the chance of a crisis, especially if countries adhere to the Guidotti-Greenspan dictum of 100 percent coverage. ${ }^{26}$ In 2001 Stan remained puzzled "that reserves should play such an important role in a flexible exchange rate system." But he conjectured that emerging market governments find reserves useful to offset fluctuations in private capital flows, thereby smoothing the path of the exchange rate.

\footnotetext{
${ }^{25}$ For analysis and pre-2000 evidence, see Reinhart and Reinhart (1999). In my dissertation, one chapter of which studied Germany's sterilization of the capital inflows of the 1960s and 1970s, I worked with a concept of the reserve-requirement adjusted monetary base. In the Bretton Woods years, the Bundesbank frequently used required reserve changes as a sterilization tool.
} 
Of course, back in 2001 it would have been hard for anyone to foresee emerging economies' huge accumulations of reserves over the subsequent years. Korea's reserves stood at $\$ 240$ billion by the eve of the Lehman Brothers failure in September 2008, for example, and they now stand near $\$ 330$ billion, about 30 percent of GDP, which approximately equals the average reserve ratio to output across all emerging and developing economies. Some of these reserves are by-products of currency intervention to preserve competitive exchange rates, but there is also an obvious precautionary motive for holding international liquidity that can be mobilized in a crisis. Logically speaking a country need not run a current account surplus to augment its reserves - it can effectively borrow them, paying a carry for the liquidity services - but the "bang for buck" in terms of immunizing the national balance sheet is much greater if the reserves are "earned" through external surpluses, so that they are owned rather than borrowed. ${ }^{27}$ However, this mode of reserve acquisition may require expenditure switching and reducing measures that impose deflation and economic distortions on trade partners. So there is a negative global "macroprudential" externality when all countries try simultaneously to improve their capital and liquidity positions. ${ }^{28}$

For Thailand, Korea, and Indonesia, Figure 11 shows reserves as a percent of total external debt liabilities (not just short-term), based on the updated data of Lane and Milesi-Ferretti (2007). Thailand's ratio of reserves to external debt are remarkable, but Korea has been maintaining nearly 100 percent coverage while Indonesian coverage,

\footnotetext{
${ }^{26}$ Feldstein (1999) had argued strongly for EMEs to self-insure through reserve acquisition.

${ }^{27}$ In addition, politicians may not appreciate the distinction - that is, they may see only the big reserve stock but not understand the associated liabilities on the national balance sheet - and their myopia could encourage policies so rash that a higher level of borrowed reserves actually destabilizes the economy. ${ }^{28}$ There are other macro externalities. For example, countries may overaccumulate reserves in the hope of appearing financially more resilient that their neighbors. For a general discussion, see Obstfeld (2014).
} 
though much lower, has been rising. For all the countries the ratios are much higher now than in the late 1990s, and this contributed to their resilience in the global crisis.

What explains these very high reserve levels, which for many EMEs substantially exceed Guidotti-Greenspan levels? Even if the demand for reserves is purely precautionary, the potential need for reserves in a crisis may go far beyond coverage of short-term foreign liabilities (an external drain). Imagine a banking crisis in which fears of devaluation emerge as the central bank provides lender-of-last-resort support. That support allows domestic residents to convert deposits into foreign exchange at the central bank (internal drain), sapping the authorities' ability to limit depreciation and meet external repayment needs. The problem may begin with banks and spill over to the exchange rate (Thailand), or start with the exchange rate and spill over to the banks (Indonesia). Either way, a better indicator of the potential need for reserves than external liabilities might be M2, or the stock of relatively liquid liabilities of the banks. This type of model is explored empirically and theoretically in Obstfeld, Shambaugh, and Taylor (2010). Boorman et al. (2000, p. 57) make the point vividly: "[T]he money that can exit if policies are perceived as unsustainable is not limited to outstanding short-term debt: rather, given the potential for domestic capital flight and speculation, a virtually bottomless pool of money would be needed [to finance the resulting capital outflow]."

High reserve stocks may also discourage private selling pressures that could weaken the domestic currency in exchange markets. This confidence channel would complement Stan's “half-instrument" of foreign-currency purchases in the task of reducing overall exchange-rate variability. The Thai baht's remarkable stability in the 
face of the recent global crisis (Figure 6) may owe something to the fact that its reserves were fully two times its foreign debt liabilities (Figure 11). ${ }^{29}$

Not only is the level of reserves important in crisis prevention and management, so is the manner in which reserves are used. If banks and corporates have extensive unmatched foreign-currency liabilities, as in many emerging markets, authorities will be keen to avoid sharp currency depreciation and may sell reserves into the market to offset depreciation pressures. However, that strategy amounts to financing capital flight, and it is both expensive and likely to fail. It will generally be more efficient to target the source of the problem by allowing the currency to depreciate (with the accompanying competitiveness gains) while reserves are supplied at a preferential rate to systemically important players, especially banks, that are unable to roll over foreign currency credits in the market. For example, according to Cho (2012, p. 66), "[I]nstead of fighting the market to protect the currency value, the [Korean] government concentrated its efforts on protecting the banking system by supplying foreign currency liquidity required to reduce the accumulated leverage." Other EME governments followed analogous strategies, to good effect. ${ }^{30}$

In these cases, the domestic central bank becomes the lender of last resort in foreign currency - at least until the IMF or a foreign central bank steps in. In his well-

\footnotetext{
${ }^{29}$ Moreover, Thailand's foreign debt liabilities, at just over 24 percent of GDP in 2008, were far below the nearly 60 percent of GDP foreign debt that the country carried into the Asian crisis. Also at work, no doubt, has been Thailand's frequent and opportunistic recourse to adjustment of both capital inflow and outflow restrictions. See Jongwanich and Kohpaiboon (2012).

${ }^{30}$ Jeanne and Wyplosz (2003) and Calvo (2006) offer insightful theoretical discussions. Ishi, Stone, and Yehoue (2009) review unconventional central bank operations during the global crisis. Korea spent about $\$ 40$ billion of its $\$ 240$ billion in reserves, but wished to keep the remaining $\$ 200$ billion in gross reserves so as to bolster market confidence; luckily, it received an additional \$30 billion swap line from the U.S. Fed. Korea was one of four EMEs - with Brazil, Mexico, and Singapore - that were offered Fed swaps.
} 
known essay on the international lender of last resort, Fischer (1999) briefly asks whether central banks should intervene in a panic through open-market operations alone (allowing the market to allocate the injected liquidity to individual institutions) or through direct loans. Writers like Humphrey and Keleher (1984) maintain that open-market operations are preferable, a position contested by Goodhart (1999) and others. In the case of reserve deployment during a crisis, it seems obvious that general sales of scarce reserves into the foreign exchange market will be much less effective than targeted lending.

As in the cases of sterilized foreign exchange intervention and unconventional monetary policies, academic studies are less unanimous about the value of international reserves than policymakers seem to be. Especially challenging is the statistical identification of the impact of reserves, which are endogenous, on outcome variables. Gourinchas and Obstfeld (2012) survey some recent econometric studies linking reserve holdings to the severity of output declines over 2008-09. For example, Blanchard, Das, and Faruqee (2010) see little link between reserve holdings and output loss in the global crisis, whereas Frankel and Saravelos (2012) and Dominguez, Hashimoto, and Ito (2012) find a positive role for reserves. In a recent paper, Bussière et al. (2013) study a large sample of emerging and developing economies and affirm a negative cross-section relation between prior reserve ratios to short-term external debt and global crisis severity. Their estimates are not overwhelmingly significant. Nonetheless, to my mind, the revealed preference of EME policymakers in accumulating reserves and quickly replenishing them when depleted (for example, after the tapering jitters during the third quarter of 2013) is relevant evidence. 
Alongside maintenance of sufficient liquid assets by the public sector, Fischer (2001a) considers debt management, by the private sector as well as the government, to be a key consideration in bolstering resilience. Of course, in a crisis the line between public and private sector debts can become blurred - Fischer (2001a) discusses at several points the extension of bank deposit guarantees in banking crises - and nothing illustrates the dangers better than the current interactions between bank stability and sovereign debts in the euro zone. Of course, the possibility of such "doom loops" is present in the Mexican and Asian crisis histories that Stan recounts, as in even earlier episodes such as the Chilean crisis that Díaz-Alejandro (1985) chronicled.

For the public sector, the asset side - consisting mainly of the present value of taxes net of expenditures - is illiquid and not hugely elastic. So, excessive debt is dangerous, especially short-maturity debt. Governments can pay domestic-currency debts in domestic money, if they are willing to inflate, but there are usually substantial foreigncurrency debts in the EME context, raising a greater likelihood of default when shortterm financing dries up. In these situations IMF credits can be indispensable; so is the IMF's role in solving collective action problems among creditors, as described in Fischer (2001a).

Without necessarily endorsing the 60 percent of GDP benchmark for gross public debt enshrined in the Maastricht treaty, Fischer (2001a, 2003) suggests that roughly half that level might be prudent for EMEs, given their vulnerabilities. This view is consistent with the "debt intolerance" hypothesis advanced by Reinhart, Rogoff, and Savastano (2003). In light of Stan's 30 percent rule of thumb, it is remarkable that average gross debt/GDP ratios for emerging economies are now actually approaching 30 percent, 
whereas for the G-7 countries, the average (heavily influenced by Japan) is around 120 percent (Figure 12). This contrast reflects not only the resilience of EMEs during the global crisis, but reforms undertaken earlier in the 2000s that allowed them to enter the crisis with significant fiscal space and mount strong countercyclical fiscal responses. The gross public debts of Thailand and Korea were low before the Asian crisis, and they rose moderately as a result. Indonesia was more heavily indebted in 1997, and its public debt rose a great deal. However, Indonesia reduced its public debt ratio from 95 percent of GDP in 2000 down to 24 percent in 2012, aided by a far-reaching tax reform initiative. ${ }^{31}$

Because the Asian crisis countries faced the need to reorganize failed banks, with possibly large costs to taxpayers, the Fund's initial programs sought to generate increased government surpluses in the short run so as to service the bank-related fiscal expenses. It was soon realized (see Fischer 2001a and Boorman et al. 2000) that the output effects of the crises had been seriously underestimated, and at that point the Fund quickly called for fiscal relaxation. But some damage had been done, both to the economies in question and, more lastingly, to the Fund's reputation in Asia. (The reluctance ever to depend again on Fund programs is often cited as one motivation behind the massive surge of Asian reserve accumulation after the late 1990s.)

In the event, the cumulative fiscal costs of bank restructuring - leaving aside any fiscal losses due to recession - were huge, far beyond what the Fund originally estimated: 44 percent of GDP in Thailand, 31 percent in Korea, and 57 percent in Indonesia (see

\footnotetext{
${ }^{31}$ See the discussion by Brondolo et al. (2008). Of course, there is considerable heterogeneity in regional public debt levels, Latin America being at the high end with debt/GDP ratios of about 50 percent on average.
} 
Laeven and Valencia 2013). However, rapid subsequent growth, due in part to structural reforms instituted as a result of the crisis, allowed these costs to be swallowed.

Notwithstanding the controversy over IMF fiscal prescriptions in the Asian crisis, the rapid growth of financial markets in many countries has clearly raised the scale of the fiscal backstop needed to ensure financial stability - as is painfully evident in Europe.

These developments therefore underline the wisdom of preserving fiscal space against the contingency of financial distress (though preferably not through severe austerity in the midst of a crisis).$^{32}$ As Fischer (2013, p. 14) concludes, referring to recent events: "[T]his crisis has reinforced the obvious belief that a country that manages itself well in normal times is likely to be better equipped to deal with the consequences of a crisis, and likely to emerge from it at lower cost.",33

Recent euro zone budgetary experience, as well as that in some other countries such as the U.K., illustrates the costs of trying to balance budgets during a deep recession, and amid continuing financial sector weakness. At this point austerity may prove counterproductive. On the other hand, government pledges to return to sustainable public debt levels over the long term may carry little credibility in the absence of strong commitment mechanisms (such as Germany has demanded in the euro area), and markets may look for some form of immediate down payment. My own view is that investment

\footnotetext{
${ }^{32}$ Acharya, Drechsler, and Schnabl (2011) model the dependence of financial stability on the scale of government guarantees, and present empirical evidence on the links between financial stability and fiscal capacity. Consistent with the views in Fischer (2001a), Boorman et al. (2000, p. 55) note that to stem a systemic banking panic may require temporary "broad based guarantees." They add: "These guarantees in turn must also be credible, requiring that public resources be available to honor them."

${ }^{33}$ Frankel, Végh, and Vuletin (2013) document how the procyclicality of fiscal policy has declined in emerging and developing countries generally; they ascribe the trend to stronger institutions. Naturally, the capacity for countercyclical fiscal response was important for EMEs in the global financial crisis, as documented in the surveys that footnote 2 mentions.
} 
in structural reform will have a bigger payoff than harsh short-term budget cutting.

Political realities make it very hard for governments to do both at the same time. ${ }^{34}$

Regarding private-sector debt management, the balance sheet problems of

corporates and firms were at the heart of the Asian crisis, and such weaknesses can help in predicting crises. ${ }^{35}$ (Household debt also can cause problems, and remains a cause for concern in some Asian countries.) A notable improvement in aggregate emerging market balance sheets generally has been a shift in external liabilities away from debt in favor of equity, portfolio or FDI (Lane and Shambaugh 2010; Prasad 2012; Forbes 2013). In response to global shocks, foreign equity holders take a hit, and debt repayment problems are correspondingly less likely. Moreover, equity liabilities are domestic-currency denominated. Higher shares of equity in gross external liabilities therefore increase resilience. For the three Asian countries, Figure 13 illustrates the behavior around crises of external equity financing, as a share of total gross external liabilities. Of course, these aggregate figures reflect decisions at the firm level, in part policy-driven. In Korea, for example, the government insisted after the Asian crisis that chaebols sharply reduce their high ratios of debt to equity (Lim 2012).

Banks still are in the business of maturity transformation, however, and their increasing reliance on non-core wholesale funding, notably in Korea and Thailand, exacerbates the risks they face. The problem of currency mismatch also remains, both in sovereign debt issue and in the private sector, although for the public sector and to some degree the corporate sector it has been reduced substantially by the growth of domestic-

\footnotetext{
${ }^{34}$ Chari and Henry (2014) and Truman (2013) compare East Asian fiscal measures during the Asian crisis with recent measures in the euro area.

${ }^{35}$ On currency crises, see, for example, Mulder, Perrelli, and Rocha (2012).
} 
currency bond markets (Mehrotra, Miyajima, and Millar 2012). ${ }^{36}$ Greater exchange-rate flexibility has also helped by reducing private incentives to take open foreign exchange positions - yet another significant benefit of abandoning a narrowly controlled exchange rate. ${ }^{37}$ But there remain concerns about hard-to-measure currency mismatches in derivatives markets.

Maturity and currency mismatches did cause problems in 2008. While the actions of domestic (and foreign) policymakers fended off disaster, Park (2011) suggests that "during the fourth quarter of 2008 Korea came close to facing insolvency of many of its financial institutions." Korean banks, especially foreign branches, exposed themselves to maturity mismatch before the global crisis by incurring short-term foreign currency liabilities to offset longer-term forward promises to deliver foreign exchange to Korean exporters and asset managers. Of course, this "hedge" disappeared once Korean banks found themselves unable to roll over foreign currency loans, leading the Bank of Korea to step in with foreign exchange reserves. Korea has since implemented measures to reduce such currency/liquidity mismatches. ${ }^{38}$

The third and last group of policy areas covered by Fischer (2001a) allows a deeper discussion of financial stability and related policies, an area intimately tied, of course, to some of the debt management questions already raised.

Capital controls, financial oversight, and transparency. Standards and transparency are meant to improve the functioning of financial markets, and so are naturally grouped with the topic of financial oversight. Capital controls figure as one

\footnotetext{
${ }^{36}$ For corporates, these markets provide an alternative to bank credit that is especially useful when bank lending is impaired.

${ }^{37}$ Kamil (2012) uses firm-level data from six Latin American countries to document the role of greater exchange-rate variability in discouraging currency mismatch.
} 
mode of mitigating the monetary trilemma, but because the policy debate increasingly refers to their macroprudential role, controls may also be discussed together with financial stability policy.

Despite the Mexican crisis of 1994, the mid-1990s generally presented an economic and political environment hospitable to the advance of financial globalization. As is well known, Stan in 1997 (Fischer 1997) endorsed the IMF's proposal for an amendment to its Articles of Agreement that would codify the Fund's role in promoting open capital markets, as well as member countries' obligation to work, gradually if need be, toward that same goal. His argument was consistent with his long-standing and oftstated belief that countries can benefit from financial openness, provided they move in that direction deliberately and with due attention to the institutional and policy prerequisites for safe liberalization of the capital account. However, the timing was terrible. Because the Asian crisis - already in progress - centered on the interplay of capital flows and domestic financial fragility, it inspired a firestorm of criticism, much of it citing potential macroprudential drawbacks of free capital flows. The IMF's plans were quietly mothballed.

In the Robbins Lectures, Stan reiterates the benefits of an official Fund role in aiding and encouraging countries to open financially. But he does not rule out temporary controls, especially of inflows, if they are useful either on prudential grounds (for example, to influence the maturity of private foreign liabilities, as the Chilean encaje apparently did), or as an aid in dampening real appreciation during disinflation. He concludes: "In a nutshell: capital controls may be useful, need to be exercised with care,

\footnotetext{
${ }^{38}$ See Chung, Park, and Shin (2012); Ree, Yoon, and Park (2012); and Bruno and Shin (2014).
} 
are likely to be transitional - albeit possibly in use for a long time - and caution is necessary in removing them."

Underlying Stan's advocacy of financial integration as a long-term goal was his confidence, expressed in the Robbins Lectures and again in his Richard T. Ely Lecture to the American Economic Association (Fischer 2003b) that open capital accounts ultimately spur long-term economic growth. Future research would establish this link decisively, he believed, in analogy with the literature on trade and growth. Where do we stand in this debate? Probably not where Stan thought we would be by now. I myself have expressed the view that the empirical evidence linking financial opening to growth is quite ambiguous (see Obstfeld 2009). Others continue to weigh in on both sides of the issue: Cline (2010), for example, argues at length that the literature supports a robust positive causal link between financial integration and growth, whereas Jeanne, Subramanian, and Williamson (2012) vigorously dispute his conclusions.

This fundamental disagreement leaves little room for academic pushback against the increasing acceptance of capital controls in the international community, both on macroprudential grounds and for the purpose of resisting real appreciation. And indeed, incremental controls have proliferated throughout the emerging world in recent years.

Regarding the macroprudential motive, the global crisis shook remaining faith in the efficiency of financial markets. Likewise, it demonstrated that even policymakers in the so-called "advanced" economies had only a very partial grasp of the accumulating vulnerabilities in their unfettered, dynamic financial markets. How could one then draw on advanced-economy experience with any confidence for lessons on the prerequisites 
for safe financial openness? $?^{39}$ In an insightful and under-appreciated essay from the turn of the millennium, Lamfalussy (2000, p. 140f) wrote of the U.S. market turmoil that followed the 1998 Russian default: "If such developments can take place in the model market of the world, what is the practical value of recommending that emerging markets copy this model?" The global crisis drove this point home with even greater force, undermining any "presumption of innocence" of large financial inflows.

The IMF has been more open lately to sanctioning inflow controls, at least on macroprudential grounds, although in reality it has long been tolerant of at least Chileanstyle measures (for example, see Boorman et al. 2000). Sometimes what can be done through capital controls can be done at least as well by macroprudential restrictions that do not discriminate between residents and nonresidents and which therefore do not amount to external payments restrictions. An example would be Korea's recent (August 2011) levy on the foreign-currency liabilities of banks, whether or not held by residents. ${ }^{40}$ Current IMF thinking is that macroprudential measures are preferred unless capital controls, used either as a substitute or complement, would yield a better outcome; for example, when significant intermediation of credit takes place outside the regulated part of the financial system (see Ostry et al. 2011).

This stance fits with the fact that not all empirical studies find large capital inflows, in and of themselves, always to be strong predictors of future crises. ${ }^{41}$ They seem to be more dangerous, however, when they coincide with domestic credit booms,

\footnotetext{
${ }^{39}$ This is not to deny that most of the prerequisites cited were, in and of themselves, selves, highly useful reforms. For an excellent summary of mainstream thinking before the global crisis, see Mishkin (2006). However, to a greater extent than most people appreciated before 2007, the advanced economies themselves were financially fragile.

${ }^{40}$ See Hahm (2012) et al.; Ree, Yoon, and Park (2012); and Bruno and Shin (2014).

${ }^{41}$ For example, Reinhart and Reinhart (2009) find that large capital inflow episodes prefigure crises in EMEs, but not necessarily in richer countries.
} 
but the evidence that capital inflows cause domestic credit booms is itself mixed. ${ }^{42}$ Thus, macroprudential measures, if feasible and effective, will often conform better than capital controls to the principle that policy interventions should target economic distortions at their sources.

As important as the macroprudential motive for controls can be, real appreciation pressures have been more important in recent practice. The resilience of emerging economies to the global crisis of 2007-09, coupled with tepid growth or stagnation in Europe, Japan, and the US, led to radically different monetary stances in these two parts of the world, with the advanced economies generally embracing extremely low interest rates and programs of quantitative easing. As a result, EMEs have faced the pressure of real appreciation ad capital inflows, the latter possibly contributing to excessively loose credit and elevated asset prices. For many, the response to this state of "currency war" has been some form of capital inflow controls, often rationalized in macroprudential terms but probably driven more by competitiveness concerns. Generally, the immediate pain in the export sector carries greater political weight than the hypothetical pain of a financial crash down the road.

In this new and difficult environment - and certainly so for the central bank of a small open economy - Stan has continued to espouse the pragmatic position he expressed in his Robbins Lectures. From Fischer (2010):

Controls are typically awkward, inefficient, inconsistent with a general pro-market approach, may discriminate against small- and medium-sized enterprises, and are frequently associated with corruption. In short, capital controls have very little to recommend them other than that they may be better than the alternatives. Policy-

\footnotetext{
${ }^{42}$ See, for example, Lane and McQuade (2014). Catão and Milesi-Ferretti (2013) find that high ratios of net foreign liabilities to GDP, as well as large current account deficits, are strong predictors of "external" crises, which comprise defaults, rescheduling events, and recourse to external official financial support.
} 
makers should make every effort to avoid using them - but central bankers should never say never.

In January 2011 Stan put this philosophy into practice when the Bank of Israel, having massively accumulated foreign exchange reserves without stopping the shekel's appreciation, imposed a 10 percent unremunerated reserve requirement on non-resident forward exchange positions and swaps (see Figure 9). Since that date, Israel's foreign exchange reserves have largely leveled out, but the shekel's exchange rate against the dollar has remained quite variable.

If capital controls are now widely regarded as kosher, then a key question going forward concerns global governance of their use, in analogy with the institutional framework for trade policy offered by the WTO. Capital controls entail externalities; for example, one country's action to shut out financial inflows may simply redirect the flows toward regional neighbors. ${ }^{43}$ A control directed at the exchange rate has obvious externalities. Thus, there are collective action problems to be solved. Are all measures to be considered admissible? What objective standards might determine if controls are justified in terms of agreed international norms? The OECD has long offered a framework for its members under its Code of Liberalization of Capital Movements and of Current Invisible Operations; in June 2012 the OECD Council invited nonmember countries voluntarily to subscribe to the Code. ${ }^{44}$

\footnotetext{
${ }^{43}$ Forbes et al. (2012) provide convincing evidence for this effect.

${ }^{44}$ On the general effectiveness of capital controls, see Jeanne, Subramanian, and Williamson (2012) - who also discuss the need for global rules of the road - and Klein (2012). The evidence is still controversial, both with respect to competitiveness and financial stability objectives, in large part because of difficult identification issues. (Controls are not imposed randomly.) The paper by Forbes, Fratzscher, and Straub (2013) is one recent attempt to overcome the identification problem and ascertain the effects of "capital flow measures" (over 2009-11) on a range of macroeconomic and financial-market outcomes. The authors conclude that the measures potentially help in attaining macroprudential, but not most macroeconomic, objectives. The exception in their study is that outflow controls do seem to affect real exchange rates.
} 
Fischer (2001a) treats the topic of strengthening financial sectors only briefly, but Stan's recent writings have been much more explicit, emphasizing the need for a macroprudential approach, including in advanced economies, and the practical difficulties of implementation. Because collapse of the financial sector was a central feature of the Asian crisis, I have often wondered if Stan, with his intimate day-to-day experience of what happened in Asia, ever thought that similar systemic financial disruptions might throw the advanced economies into deep recession. Fischer (2013, p. 3) discloses his thoughts as follows:

The crisis has been far worse in many of the advanced countries - the United States, the United Kingdom, and some other European countries - than it has been in the leading emerging market countries. This was not the situation in the financial crises of the 1990s, and it is not a situation that I expected would ever occur.

The critical difference between countries that have suffered from exceptionally deep crises and those that have had a more or less standard business cycle experience during this crisis traces to what happened in their financial sectors. Those countries that suffered financial sector crises had much deeper output crises.

Two mutually reinforcing limitations in mainstream economic policy frameworks allowed this aspect of the global financial crisis to come as a surprise. First, standard macroeconomic models did not adequately capture the central role of financial markets, including the possibility that those markets could freeze under the weight of microeconomic frictions. Second, and conversely, the regulatory approaches previously used to address these frictions largely failed to keep in mind the macroeconomic dimension, thereby falling prey to fallacies of composition. ${ }^{45}$ Both of these shortcomings are now much better appreciated and they inspire much of current macro research and financial policy reform. Perhaps the dangers could have been better anticipated ex ante, however, in light of earlier EME crises.

\footnotetext{
${ }^{45}$ Brunnermeier et al. (2009) offer an excellent discussion.
} 
Economists have recently placed a renewed emphasis on rapid domestic credit expansion as a predictor of crises, in line with the Minsky-Kindleberger tradition; with the important Kaminsky-Reinhart (1999) empirical evidence on twin banking and currency crises; and with earlier warnings about the financial cycle by BIS economists such as Andrew Crockett, Claudio Borio, and William White. (For some recent findings see Dell'Ariccia et al. 2012, Gourinchas and Obstfeld 2012, Schularick and Taylor 2012, and references therein.)

Figure 14 shows domestic credit-to-GDP ratios for Thailand, Korea, and Indonesia. These data must be approached with caution because the series sometimes break due to changes in coverage (as is especially obvious for Korea after 2000). If these data are to be believed, all three countries had run-ups in credit prior to the Asian crisis, though Thailand's credit growth preceding 1997 was epic. Indonesia's credit ratio has been in decline since the Asian crisis, while the Korean and Thai rates of credit growth were high just prior to the global financial crisis. ${ }^{46}$

Korean credit growth generally has slowed since 2008, but recent Thai credit growth bears watching, as does credit growth in a number of other emerging economies. Accurate diagnosis of impending problems is not always straightforward, however, and would have to rely on a range of indicators, as there are many instances in which credit booms have not ended in tears (as discussed in detail by Dell'Ariccia et al. 2012). Thus, it is difficult to say on the basis of credit data alone whether the three countries were financially on a safer footing than a decade earlier on the eve of the global crisis.

\footnotetext{
${ }^{46}$ Closely related to domestic credit is another indicator of the credit cycle, the non-core liabilities of the financial sector. Hahm et al. (2012) discuss this aggregate, paying special attention to the Korean case, along with macroprudential tools that are available in an EME context. See also Claessens and Ghosh (2012). Non-core liabilities of Korean banks grew quite rapidly prior to both the Asian and Lehman crises.
} 
We do have additional information, however. Thailand, Korea, and Indonesia all took measures to strengthen their financial systems after the Asian crisis. They cleaned financial institutions' balance sheets, tightened supervision and regulation, pushed for better risk-management practices, and reorganized some business groups. In Korea, a national credit-card crisis nonetheless erupted in 2003, but this spurred tighter controls over domestic credit. The countries have also paid attention to the macroprudential dangers posed by leverage in real estate markets (Park 2011; Oh 2013). But, as noted above, currency and maturity mismatches remain potentially problematic, and did cause some difficulties during the global crisis, notably for Korea (which has, however, taken measures to reduce them - as noted earlier). As a result of the global financial crisis, all of the countries went further in fortifying prudential oversight and regulation of their financial systems. Currently, high levels of household debt in Korea and Thailand remain a cause for worry, while Indonesia in 2012-13 imposed and then lowered a maximum loan-to-value ratio for housing loans.

Regarding transparency, a major IMF initiative that has promoted availability of timely and accurate financial data is the Special Data Dissemination Standard (or SDDS, inspired by the mid-1990s Mexican crisis). All three Asian countries first met the SDDS transparency standards shortly after the Asian crisis: Korea in late 1999 and Indonesia and Thailand in the first half of 2000. Particularly important is transparency with respect to international reserves - in view of the largely unanticipated near-exhaustion of Thai and Korean resources as the Asian crisis emerged. Reported reserves data include derivatives positions. Indonesia and Korea provide them on a monthly basis, Thailand on a weekly basis. 
Coupled with flexible exchange rates, the public availability of such data allows for a gradual buildup of market pressure that hopefully induces prompter policy adjustment. Fischer (2001a) suggests that public availability of reserves data may help to mobilize domestic political pressure against unsustainable policies. On the other hand, I have noted above that the inverse proposition might also hold true, with effects that are not helpful: information that reserves are high - even when reserves might bleed out very quickly - could lull the political powers into a false sense of security. Another concern (also noted above) is that the transparency of reserve levels might induce countries to accumulate them excessively in a bid to build credibility relative to neighboring countries. The same considerations can make countries reluctant to actually use reserves when they need them most, as the experience of Korea in the global crisis illustrates. My judgment is that the benefits of reserve transparency outweigh any costs, though the costs could be reduced were self-insurance through reserve accumulation supplemented or replaced by some politically acceptable form of official mutual credit lines. ${ }^{47}$

The SDDS is only one component of the work done by the Fund and the World Bank to monitor and publicize compliance with a range of international standards for financial markets and activities (see the Reports on the Observance of Standards and Codes produced by the Fund and the Bank). This essential machinery of detailed, standardized, financial surveillance owes a lot to Stan Fischer's leadership while at the IMF. Greater transparency in this regard not only has the potential to limit the kind of contagion that erupted in Asia in 1997-98; transparency can also induce governments to address financial problems more quickly.

\footnotetext{
${ }^{47}$ See, for example, Farhi, Gourinchas, and Rey 2011; Park 2011; and Obstfeld 2014.
} 


\section{Conclusion}

At the start of this paper I posed four questions inspired by Stan's 2001 Robbins

Lectures: Did emerging markets largely follow his 2001 recommendations? Did these steps help? What additional policies and reforms also helped? Finally, what further lessons does the post-2001 period offer?

It is difficult to generalize about a large and diverse group of economies, yet a number of conclusions seem to be broadly accurate. Emerging markets by and large did conform to Stan's prescriptions -- they had been moving in that direction (some under the IMF's prodding) even when Stan presented his lectures at the LSE. Exchange rates are now more flexible than in the late 1990s and EMEs have benefited from monetary frameworks, such as formal inflation targeting, that deliver moderate and stable inflation. Levels of foreign exchange reserves are high - indeed, much higher in many cases than Stan would have predicted - and a combination of robust growth and fiscal reform has led to moderate public debt levels. EMEs have greatly strengthened their financial systems and embraced higher standards of transparency for government data and policies. Currency mismatches, while far from eliminated, were reduced. While it is difficult to assess the counterfactuals, such evidence as we can assemble suggests these measures were very helpful in helping EMEs weather the global financial crisis as well as they $\operatorname{did}^{48}$

Other developments helped as well. For example, the shift in EME national liabilities away from debt and toward equity is important - it can be solidified and encouraged through further reforms in corporate governance. Growth in domestic- 
currency bond markets, with significant foreign participation in many cases, has been important in reducing currency mismatch on the public balance sheet. In turn, the improvements in both inflation and fiscal management created essential preconditions for the popularity of domestic-currency bonds. EMEs have deployed their large international reserve stocks with considerable flexibility to play the role of LLR in foreign currencies.

Related to this success, however, Fischer's (1999) hope that the IMF would evolve into a global LLR has not come to pass. Flexible pre-approved Fund credit lines, whether inspired by the Asian crisis or the global crisis a decade later, seem to have had limited appeal to their target market. At this point the heavy commitment of Fund resources to Europe leads some potential client countries even to doubt the extent of resources that would be available in a new global crisis - one caused, for example, by a reversal in U.S. monetary policy or a U.S. fiscal accident. Thus, EME accumulation of gross reserves, with the attendant externalities, will continue.

What have we learned that is new from the global crisis and its aftermath? One important lesson is that advanced economies are not immune to the type of virulent financial infection central to the Asian crisis. As a result, enhancing micro- as well as macroprudential defenses is high on the agenda in richer countries, with special urgency currently in the euro zone.

Macroprudential motives have created a new openness to capital inflow controls in the international community, but a second motivation, at least as important, is the monetary policy trilemma. While the exchange rate has been widely discarded as the primary nominal anchor, exchange-rate variability is far from being a matter of policy

\footnotetext{
${ }^{48}$ Of course China's rapid growth in recent years has also helped power EMEs from Brazil to Africa to Russia. While Stan in 2001 alluded to the regional importance of China, it was not yet clear how quickly
} 
indifference. One response has been extensive foreign exchange intervention, another is to throw sand in the wheels of cross-border finance. Under Stan's governorship, the Bank of Israel eventually embraced both tools despite long-held reservations.

The global crisis has highlighted questions about potential negative externalities from financial markets. In light of serious instability in countries with supposedly highquality civil and economic institutions, one is less confident than a decade ago about the risk-benefit tradeoff from the global growth of finance. "Financial development" could be a mixed blessing for EMEs to the extent that greater integration with the global financial market implies greater vulnerability to its vicissitudes. Witness the severe shock that Korea, with its relatively sophisticated and open asset markets, experienced in 2008-09. Events since the Asian crisis have only reinforced the message, clearly present in Stan's earlier and recent writings alike, that globalization needs to be managed with care.

China would become a key global source of demand. 


\section{References}

Acharya, Viral V., Itamar Drechsler, and Philipp Schnabl. “A Pyrrhic Victory? Bank Bailouts and Sovereign Credit Risk.” Working Paper 17136, National Bureau of Economic Research, June 2011.

Aizenman, Joshua and Reuven Glick. "Sterilization, Monetary Policy, and Global Financial Integration.” Review of International Economics 17 (September 2009): 777801.

Argy, Victor and Pentti J. K. Kouri. "Sterilization Policies and the Volatility in International Reserves." In Robert Z. Aliber, ed., National Monetary Policies and the International Financial System. Chicago: University of Chicago Press, 1974.

Benes, Jaromir, Andrew Berg, Rafael A. Portillo, and David Vavra. "Modeling Sterilized Interventions and Balance Sheet Effects of Monetary Policy in a New-Keynesian Framework.” IMF Working Paper WP/13/11, January 2013.

Bernanke, Ben S., Vincent R. Reinhart, and Brian P. Sack. "Monetary Policy Alternatives at the Zero Bound: An Empirical Assessment." Brookings Papers on Economic Activity 35 (2, 2004): 1-100.

Blanchard, Olivier J., Mitali Das, and Hamid Faruqee. "The Initial Impact of the Crisis on Emerging Market Countries.” Brookings Papers on Economic Activity 41 (1, 2010): 263-307.

Blanchard, Olivier J. and Jordi Galí. "Real Wage Rigidities and the New Keynesian Model." Journal of Money, Credit, and Banking 39 (1, 2007): Supplement, 35-65.

Bodenstein, Martin, Luca Guerrieri, and Lutz Kilian. "Monetary Policy in Response to Oil Price Fluctuations." IMF Economic Review 60 (4, 2012): 470-504.

Boorman, Jack, Timothy Lane, Marianne Schulze-Ghattas, Aleš Buliřr, Atish R. Ghosh, Javier Hamann, Alex Mourmouras, and Steven Phillips. "Managing Financial Crises: The Experience of East Asia." Carnegie-Rochester Conference Series on Public Policy 53 (2000): 1-67.

Brondolo, John, Carlos Silvani, Eric Le Borgne, and Frank Bosch. "Tax Administration Reform and Fiscal Adjustment: The Case of Indonesia (2001-07).” IMF Working Paper WP/08/129, May 2008.

Brunnermeier, Markus, Andrew Crockett, Charles Goodhart, Avinash D. Persaud, and Hyun Shin. The Fundamental Principles of Financial Regulation. $11^{\text {th }}$ Geneva Report on the World Economy. Geneva and London: Centre for Monetary and Banking Studies and Centre for Economic Policy Research, 2009. 
Bruno, Valentina and Hyun Song Shin. “Assessing Macroprudential Policies: Case of Korea." Scandinavian Journal of Economics 116 (2014), forthcoming.

Bussière, Matthieu, Gong Cheng, Menzie Chinn, and Noëmie Lisack. "International Reserves and the Global Financial Crisis.” Mimeo, September 2013.

Calvo, Guillermo A. "Monetary Policy Challenges in Emerging Markets: Sudden Stop, Liability Dollarization, and Lender of Last Resort." Working Paper 12788, National Bureau of Economic Research, December 2006.

Calvo, Guillermo A. and Carmen M. Reinhart. "Fear of Floating." Quarterly Journal of Economics 117 (May 2002): 379-408.

Canzoneri, Matthew, Robert Cumby, Behzad Diba, and David López-Salido. "Monetary Aggregates and Liquidity in a Neo-Wicksellian Framework." Journal of Money, Credit, and Banking 40 (December 2008): 1667-1698.

Catão, Luis A. V. and Gian Maria Milesi-Ferretti. "External Liabilities and Crises." IMF Working Paper WP/13/113, May 2013.

Ceballos, Francisco, Tatiana Didier, Constantino Hevia, and Sergio Schmukler. "Policy Responses to the Global Financial Crisis: What Did Emerging Economies Do Differently?" Documento de Trabajo 2013-002, Banco Central de Reserva del Perú, January 2013.

Chari, Anusha and Peter Blair Henry. "Two Tales of Adjustment: East Asian Lessons for European Growth.” IMF Economic Review 2014, this issue.

Cho, Dongchul. "Responses of the Korean Economy to the Global Economic Crisis: Another Currency Crisis?" In Maurice Obstfeld, Dongchul Cho, and Andrew Mason, eds., Global Economic Crisis: Impacts, Transmission, and Recovery. Cheltenham, UK: Edward Elgar, 2012.

Chung, Jaesik, Yongseung Jung, and Doo Yong Yang. "Optimal Monetary Policy in a Small Open Economy: The Case of Korea." Journal of Asian Economies 18 (1, 2007): 125-143.

Chung, Kyuil, Hail Park, and Hyun Song Shin. "Mitigating Systemic Spillovers from Currency Hedging." National Institute Economic Review (221, July 2012): R44-R56.

Claessens, Stijn and Swati R. Ghosh. "Macro-Prudential Policies: Lessons for and from Emerging Markets." Forthcoming in proceedings of the KDI/EWC conference "Financial Regulations on International Capital Flows and Exchange Rates," University of Hawaii, Manoa, July 2012. At: http://www.g24.org/TGM/Macro-Prudential\%20Policies.pdf 
Claessens, Stijn, M. Ayhan Kose, Luc Laeven and Fabián Valencia, eds. Financial Crises: Causes, Consequences, and Policy Responses. Washington, D.C.: International Monetary Fund, 2014.

Cline, William R. Financial Globalization, Economic Growth, and the Crisis of 2007-09. Washington, D.C.: Peterson Institute for International Economics, 2010.

de Carvalho Filho, Irineu E. " 28 Months Later: How Inflation Targeters Outperformed Their Peers in the Great Recession.” B.E. Journal of Macroeconomics 11 (Topics, July 2011), Article 22.

De Gregorio, José. "Policy Corner: Commodity Prices, Monetary Policy, and Inflation." IMF Economic Review 60 (4, 2012): 600-633.

De Gregorio, José and Roberto Alvarez. "Why Did Latin America and Developing Countries Perform Better in the Global Financial Crisis than in the Asian Crisis?" IMF Economic Review 2014, this issue.

Dell'Ariccia, Giovanni, Deniz Igan, Luc Laeven, and Hui Tong. "Policies for Macrofinancial Stability: How to Deal with Credit Booms." IMF Staff Discussion Note SDN/12/06, June 2012.

Díaz-Alejandro, Carlos F. "Good-bye Financial Repression, Hello Financial Crash." Journal of Development Economics 19 (September-October 1985): 1-24.

Didier, Tatiana, Constantino Hevia, and Sergio Schmukler. "How Resilient and Countercyclical Were Emerging Economies during the Global Financial Crisis?" Journal of International Money and Finance 31 (December 2012): 2052-2077.

Disyatat, Piti and Gabriele Galati. "The Effectiveness of Foreign Exchange Intervention in Emerging Market Countries: Evidence from the Czech Koruna." Journal of International Money and Finance 26 (April 2007): 383-402.

Dominguez, Kathryn M. E., Yuko Hashimoto, and Takatoshi Ito. "International Reserves and the Global Financial Crisis." Journal of International Economics 88 (2, 2012): 388406.

Dornbusch, Rudiger. "Brazil's Incomplete Stabilization and Reform.” Brookings Papers on Economic Activity 28 (1, 1997): 367-404.

Edwards, Sebastian. "The Relationship between Exchange Rates and Inflation Targeting Revisited.” In Frederic S. Mishkin and Klaus Schmidt-Hebbel, eds., Monetary Policy under Inflation Targeting. Santiago, Chile: Central Bank of Chile, 2007. 
Eichengreen, Barry. "Monetary and Exchange Rate Policy in Korea: Assessments and Policy Issues.” Discussion Paper 4676, Centre for Economic Policy Research, October 2004.

Elekdag, Selim, Alejandro Justiniano, and Ivan Tchakarov. "An Estimated Small Open Economy Model of the Financial Accelerator.” IMF Staff Papers 53 (2, 2006): 219-241.

Farhi, Emmanuel, Pierre-Olivier Gourinchas, and Hélène Rey. Reforming the International Monetary System. London: Centre for Economic Policy Research, September 2011.

Feldstein, Martin. “A Self-Help Guide for Emerging Markets.” Foreign Affairs 78 (2, 1999): 93-109.

Fischer, Stanley, "Capital Account Liberalization and the Role of the IMF." Paper presented at the seminar "Asia and the IMF," Hong Kong, China, September 19, 1997.

Fischer, Stanley. "On the Need for an International Lender of Last Resort.” Journal of Economic Perspectives 13 (Fall 1999): 85-104.

Fischer, Stanley. The International Financial System: Crises and Reform. The Robbins Lectures at the London School of Economics, October 29-31, 2001. Manuscript, 2001a.

Fischer, Stanley. "Exchange Rate Regimes: Is the Bipolar View Correct?" Journal of Economic Perspectives 15 (Spring 2001b): 3-24

Fischer, Stanley. "Financial Crises and Reform of the International Financial System." Review of World Economics 139 (1, 2003a): 1-37.

Fischer, Stanley. "Globalization and Its Challenges.” American Economic Review 93 (May 2003b): 1-30.

Fischer, Stanley. "Mundell-Fleming Lecture: Exchange Rate Systems, Surveillance, and Advice." IMF Staff Papers 55 (3, 2008): 367-383.

Fischer, Stanley. "Panel Discussion.” In Christopher Kent and Michael Robson, eds., Reserve Bank of Australia 50 ${ }^{\text {th }}$ Anniversary Symposium. Sydney: Reserve Bank of Australia, 2010.

Fischer, Stanley. "Introduction: Central Bank Lessons from the Global Crisis." In Jacob Braude, Zvi Eckstein, Stanley Fischer, and Karnit Flug, eds., The Great Recession: Lessons for Central Bankers. Cambridge, MA: MIT Press, 2013.

Forbes, Kristin J. "The 'Big C': Identifying and Mitigating Contagion." In The Changing Policy Landscape: A Symposium Sponsored by the Federal Reserve Bank of Kansas City. Kansas City, MO: Federal Reserve Bank of Kansas City, 2013, pp. 23-87. 
Forbes, Kristin J., Marcel Fratzscher, Thomas Kostka, and Roland Straub. "Bubble Thy Neighbor: Portfolio Effects and Externalities from Capital Controls." Working Paper 18052, National Bureau of Economic Research, May 2012.

Forbes, Kristin J., Marcel Fratzscher, and Roland Straub. "Capital Controls: What Are They Good For?” Mimeo, MIT, DIW, and ECB, September 2013. At:

http://web.mit.edu/kjforbes/www/Papers/2013-09-18-Forbes-What\%20Are\%20They\%20Good\%20For.pdf

Frankel, Jeffrey A. "Monetary Policy in Emerging Markets." In Benjamin M. Friedman and Michael Woodford, eds., Handbook of Monetary Economics, vol. 3. Amsterdam: Elsevier, 2010.

Frankel, Jeffrey and George Saravelos. "Can Leading Indicators Assess Country Vulnerability? Evidence from the 2008-09 Global Financial Crisis.” Journal of International Economics 87 (2, 2012): 216-231.

Frankel, Jeffrey A., Carlos A. Végh, and Guillermo Vuletin. "On Graduation from Fiscal Procyclicality." Journal of Development Economics 100 (1, 2013): 32-47.

Gertler, Mark, Simon Gilchrist, and Fabio M. Natalucci. "External Constraints on Monetary Policy and the Financial Accelerator." Journal of Money, Credit, and Banking 39 (March-April 2007): 295-330.

Gertler, Mark and Peter Karadi. "A Model of Unconventional Monetary Policy.” Journal of Monetary Economics 58 (January 2011): 17-34.

Goldstein, Itay and Assaf Razin. Understanding Global Crises. Cambridge, MA: MIT Press, 2014.

Goldstein, Morris, and Daniel Xie. "The Impact of the Financial Crisis on Emerging Asia." In Reuven Glick and Mark M. Spiegel, eds., Asia and the Global Financial Crisis. San Francisco: Federal Reserve Bank of San Francisco, 2010.

Goodhart, Charles A. E. "Myths about the Lender of Last Resort." International Finance 2 (November 1999): 339-360.

Gourinchas, Pierre-Olivier and Maurice Obstfeld. "Stories of the Twentieth Century for the Twenty-First." American Economic Journal: Macroeconomics 4 (January 2012): 226265.

Grenville, Stephen and Takatoshi Ito. An Independent Evaluation of the Bank of Thailand's Monetary Policy under the Inflation Targeting Framework, 2000-2010. Bangkok: Bank of Thailand, 2010. At:

http://www.bot.or.th/Thai/MonetaryPolicy/Documents/GrenvilleItoV10\%28Oct22\%29.pdf 
Hahm, Joon-Ho, Frederic Mishkin, Hyung Song Shin, and Kwanho Shin.

"Macroprudential Policies in Open Emerging Economies." In Reuven Glick and Mark M. Spiegel, eds., Asia's Role in the Post-Crisis Global Economy. San Francisco: Federal Reserve Bank of San Francisco, 2012.

Hammond, Gill. State of the Art of Inflation Targeting. Handbook No. 29. London: Bank of England Centre for Central Banking Studies, 2012.

Humphrey, Thomas M. and Robert E. Keleher. "The Lender of Last Resort: A Historical Perspective." Cato Journal 4 (1, 1984): 275-317.

Ishi, Kotaro, Mark Stone, and Etienne B. Yehoue. "Unconventional Central Bank Measures for Emerging Economies.” IMF Working Paper WP/09/226, October 2009.

Ito, Takatoshi, and Tomoko Hayashi. "Inflation Targeting in Asia." Occasional Paper No. 1, Hong Kong Institute for Monetary Research, March 2004.

Jeanne, Olivier, Arvind Subramanian, and John Williamson. Who Needs to Open the Capital Account? Washington, D.C.: Peterson Institute for International Economics, 2012.

Jeanne, Olivier and Charles Wyplosz. "The International Lender of Last Resort: How Big Is Big Enough?” In Michael P. Dooley and Jeffrey A. Frankel, eds., Managing Currency Crises in Emerging Markets. Chicago: University of Chicago Press, 2003.

Jongwanich, Juthathip and Archanun Kohpaiboon. "Effectiveness of Capital Controls: Evidence from Thailand.” Asian Development Review 29 (2, 2012): 50-93.

Kamil, Herman. "Is Central Bank Intervention Effective under Inflation Targeting Regimes? The Case of Colombia.” IMF Working Paper WP/08/88, April 2008.

Kamil, Herman. "How Do Exchange Rate Regimes Affect Firms' Incentives to Hedge Currency Risk? Micro Evidence for Latin America.” IMF Working Paper WP/12/69, March 2012.

Kaminsky, Graciela L. and Carmen M. Reinhart. "The Twin Crises: The Causes of Banking and Balance-of-Payments Problems." American Economic Review 89 (June 1999): 473-500.

Klein, Michael W. "Capital Controls: Gates versus Walls." Brookings Papers on Economic Activity 43 (2, 2012): 317-355.

Klein, Michael W. and Jay C. Shambaugh. "Rounding the Corners of the Policy Trilemma: Sources of Monetary Policy Autonomy." Working Paper 19461, National Bureau of Economic Research, September 2013. 
Kouri, Pentti J. K. and Michael G. Porter. "International Capital Flows and Portfolio Equilibrium.” Journal of Political Economy 82 (May-June 1974): 443-467.

Kose, M. Ayhan and Eswar S. Prasad. Emerging Markets: Resilience and Growth amid Global Turmoil. Washington, D.C.: Brookings Institution, 2010.

Krishnamurthy, Arvind and Annette Vissing-Jorgensen. "The Effects of Quantitative Easing on Interest Rates: Channels and Implications for Policy." Brookings Papers on Economic Activity 42 (2, 2011): 215-265.

Krishnamurthy, Arvind and Annette Vissing-Jorgensen. "The Ins and Outs of LSAPs." Proceedings of the Federal Reserve Bank of Kansas City 2013 Economic Policy Symposium, Jackson Hole, WY.

Krugman, Paul. "Balance Sheets, the Transfer Problem, and Financial Crises." International Tax and Public Finance 64 (4, 1999): 459-472.

Krugman, Paul R., Maurice Obstfeld, and Marc J. Melitz. International Economics: Theory and Policy, 10 ${ }^{\text {th }}$ edition. Upper Saddle River, NJ: Pearson, 2015.

Laeven, Luc and Fabián Valencia. "Systemic Banking Crises Database." IMF Economic Review 61 (2, 2013): 225-270.

Lahiri, Amartya and Carlos Végh. "Delaying the Inevitable: Interest Rate Defense and Balance of Payments Crises." Journal of Political Economy 111 (April 2003): 404-424.

Lamfalussy, Alexandre. Financial Crises in Emerging Markets: An Essay on Financial Globalization and Fragility. New Haven, CT: Yale University Press, 2000.

Lane, Philip R. and Peter McQuade. "Domestic Credit Growth and International Capital Flows." Scandinavian Journal of Economics 116 (2014), forthcoming.

Lane, Philip R. and Gian Maria Milesi-Ferretti. “The External Wealth of Nations, Mark II: Revised and Extended Estimates of Foreign Assets and Liabilities, 1970-2004." Journal of International Economics 73 (November 2007): 223-250.

Lane, Philip R. and Jay C. Shambaugh. "Financial Exchange Rates and International Currency Exposures.” American Economic Review 100 (March 2010): 518-540.

Lim, Kyung-Mook. "Structural Fundamentals of Korean Corporations: This Time Was Different." In Maurice Obstfeld, Dongchul Cho, and Andrew Mason, eds., Global Economic Crisis: Impacts, Transmission, and Recovery. Cheltenham, UK: Edward Elgar, 2012.

McKinnon, Ronald I. and Huw Pill. "Credible Economic Liberalizations and Overborrowing.” American Economic Review 87 (May 1997): 189-193. 
Mehrotra, Aaron. "On the Use of Sterilisation Bonds in Emerging Asia." Manuscript, Bank for International Settlements, January 2012.

Mehrotra, Aaron, Ken Miyajima, and Agustín Millar. "Developments of Domestic Government Bond Markets in EMEs and Their Implications.” BIS Papers 67, October 2012.

Mishkin, Frederic S. The Next Great Globalization. Princeton, NJ: Princeton University Press, 2006.

Monacelli, Tommaso. "Is Monetary Policy in an Open Economy Fundamentally Different?" IMF Economic Review 61 (1, 2013): 6-21.

Montiel, Peter J. Ten Crises. London: Routledge, 2013.

Mulder, Christian, Roberto Perrelli, and Manuel Duarte Rocha. "External Vulnerability, Balance Sheet Effects, and the Institutional Framework - Lessons from the Asian Crisis." International Review of Economics and Finance 21 (2012): 16-28.

Obstfeld, Maurice. "Imperfect Asset Substitutability and Monetary Policy under Fixed Exchange Rates.” Journal of International Economics 10 (May 1980): 177-200.

Obstfeld, Maurice. "International Finance and Growth in Developing Countries: What Have We Learned?” IMF Staff Papers 56 (1, 2009): 63-111.

Obstfeld, Maurice. "The International Monetary System: Living with Asymmetry." In Robert C. Feenstra and Alan M. Taylor, eds., Globalization in an Age of Crisis: Multilateral Economic Cooperation in the Twenty-First Century. Chicago: University of Chicago Press, 2014.

Obstfeld, Maurice, Jay C. Shambaugh, and Alan M. Taylor. "The Trilemma in History: Tradeoffs among Exchange Rates, Monetary Policies, and Capital Mobility." Review of Economics and Statistics 87 (August 2005): 423-438.

Obstfeld, Maurice, Jay C. Shambaugh, and Alan M. Taylor. "Financial Stability, the Trilemma, and International Reserves." American Economic Journal: Macroeconomics 2 (April 2010): 57-94.

Oh, Hwa Se. "Loan-to-Value as Macro-Prudential Policy Tool: Experiences and Lessons of Asian Emerging Economies." Policy Paper 33, Duisenberg School of Finance, January 2013.

Ostry, Jonathan D., Atish R, Ghosh, and Marcos Chamon. "Two Targets, Two Instruments: Monetary and Exchange Rate Policies in Emerging Market Economies." IMF Staff Discussion Note SDN/12/01, February 2012. 
Ostry, Jonathan D., Atish R. Ghosh, Karl Habermeier, Luc Laeven, Marcos Chamon, Mahvash S. Qureshi, and Annamaria Kokenyne. "Managing Capital Inflows: What Tools to Use?” IMF Staff Discussion Note SDN/11/06, April 2011.

Park, Yung Chul. "The Role of Macroprudential Policy for Financial Stability in East Asia's Emerging Economies.” Asian Development Bank Institute Working Paper Series No. 284, May 2011.

Prasad, Eswar S. "Role Reversal in Global Finance." In Achieving Maximum Long-Run Growth: A Symposium Sponsored by the Federal Reserve Bank of Kansas City.. Kansas City, MO: Federal Reserve Bank of Kansas City, 2012, pp. 339-390.

Ree, Jack Joo K., Kyoungsoo Yoon, and Hail Park. "FX Funding Risks and Exchange Rate Volatility_Korea's Case.” IMF Working Paper WP/12/268, November 2012.

Reinhart, Carmen M. and Vincent R. Reinhart. "On the Use of Reserve Requirements in Dealing with Capital Flow Problems." International Journal of Finance and Economics 4 (January 1999): 27-54.

Reinhart, Carmen M. and Vincent R. Reinhart. "Capital Flow Bonanzas: An Encompassing View of the Past and Present." In Jeffrey A. Frankel and Christopher Pissarides, eds., International Seminar on Macroeconomics 2008. Chicago: University of Chicago Press, 2009.

Reinhart, Carmen M., Kenneth S. Rogoff, and Miguel A. Savastano. "Debt Intolerance." Brookings Papers on Economic Activity 34 (1, 2003): 1-74.

Rey, Hélène. "Dilemma not Trilemma: The Global Financial Cycle and Monetary Policy Independence." Proceedings of the Federal Reserve Bank of Kansas City 2013 Economic Policy Symposium, Jackson Hole, WY.

Sánchez, Marcelo. "Characterising the Inflation Targeting Regime in South Korea." Working Paper 1004, European Central Bank, February 2009.

Schularick, Moritz and Alan M. Taylor. "Credit Booms Gone Bust: Monetary Policy, Leverage Cycles, and Financial Crises, 1870-2008." American Economic Review 102 (April 2012): 1029-1061.

Stone, Mark, Scott Roger, Seiichi Shimizu, Anna Nordstrom, Turgut Kışınbay, and Jorge Restrepo. The Role of the Exchange Rate in Inflation-Targeting Emerging Economies. Occasional Paper 267. Washington, D.C.: International Monetary Fund, 2009.

Truman, Edwin M. "Asian and European Financial Crises Compared.” Working Paper WP 13-9, Peterson Institute for International Economics, October 2013. 
Figure 1: Real Output around Crises

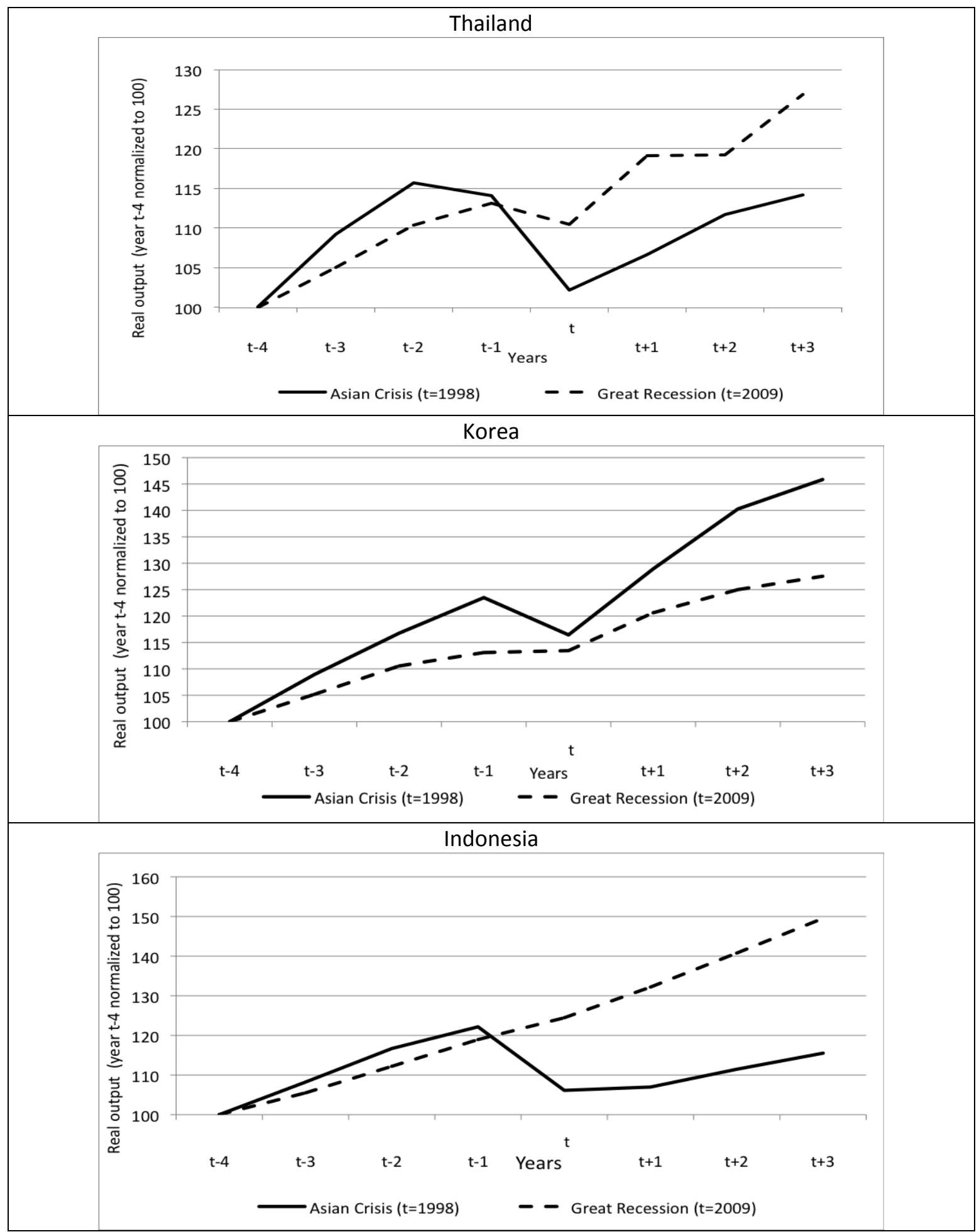

Source: IMF, World Economic Outlook database, April 2013. 
Figure 2: The Current Account around Crises

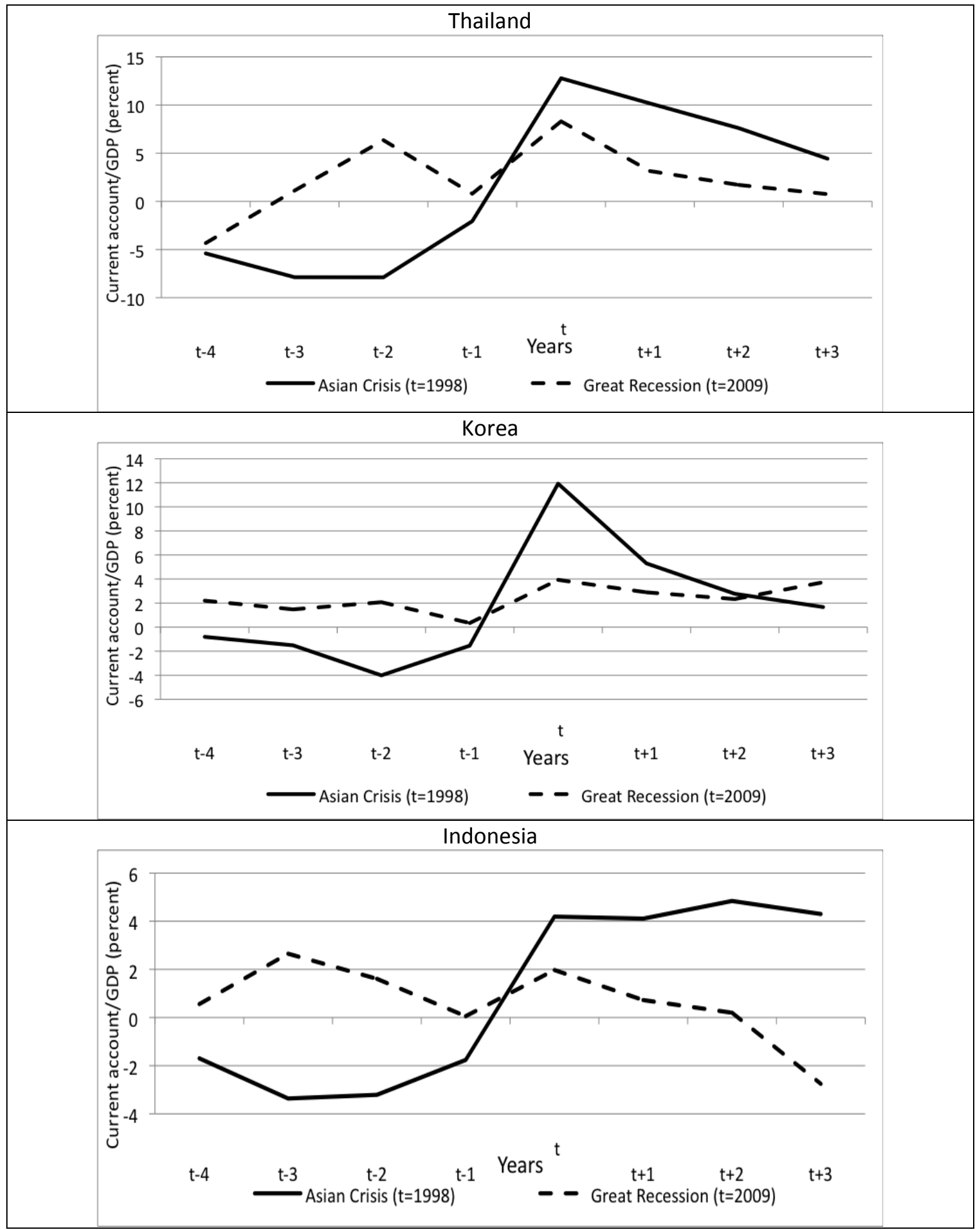

Source: IMF, World Economic Outlook database, April 2013. 
Figure 3: Investment Rates around Crises

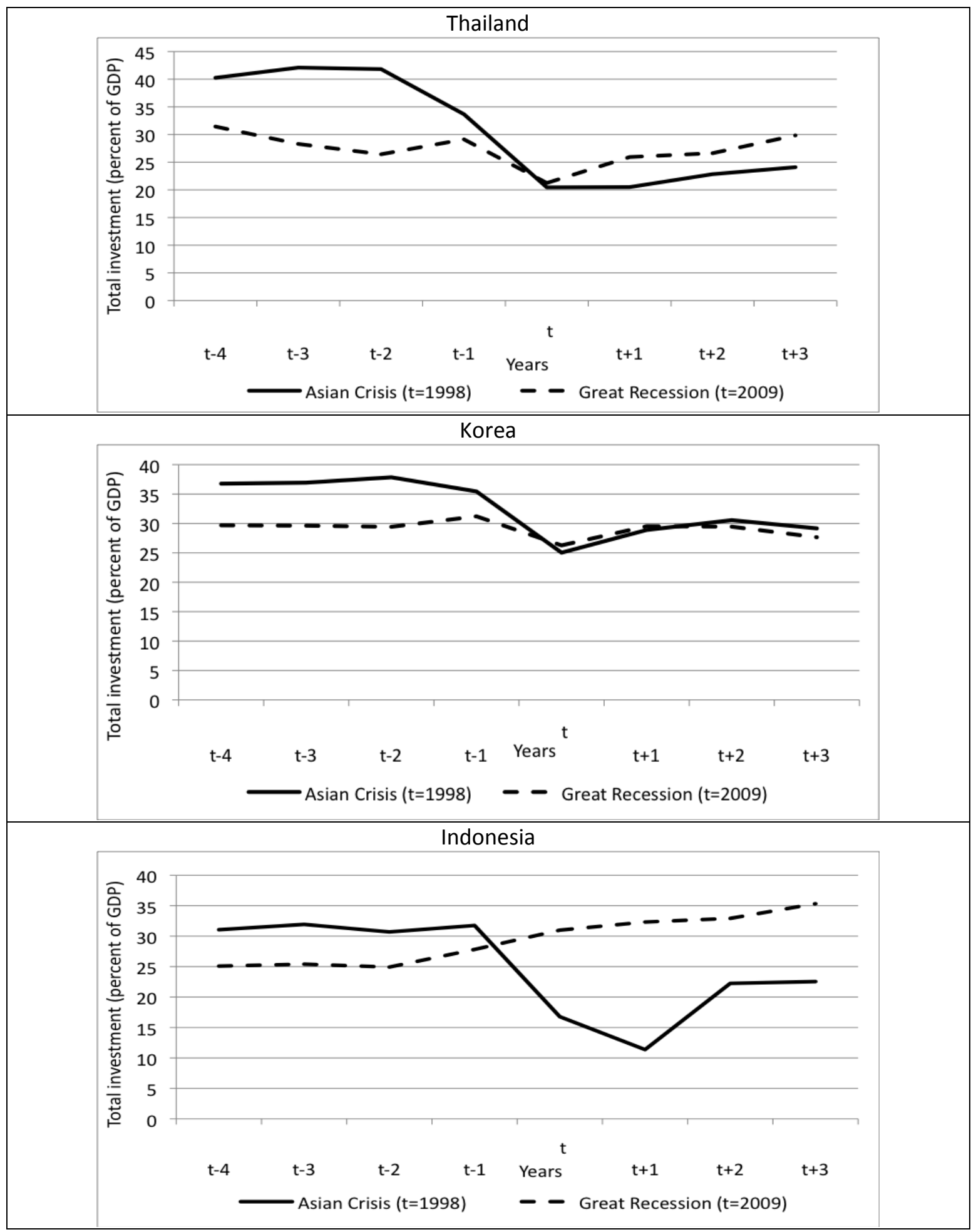

Source: IMF, World Economic Outlook database, April 2013. 
Figure 4: Headline Inflation Compared to Targets

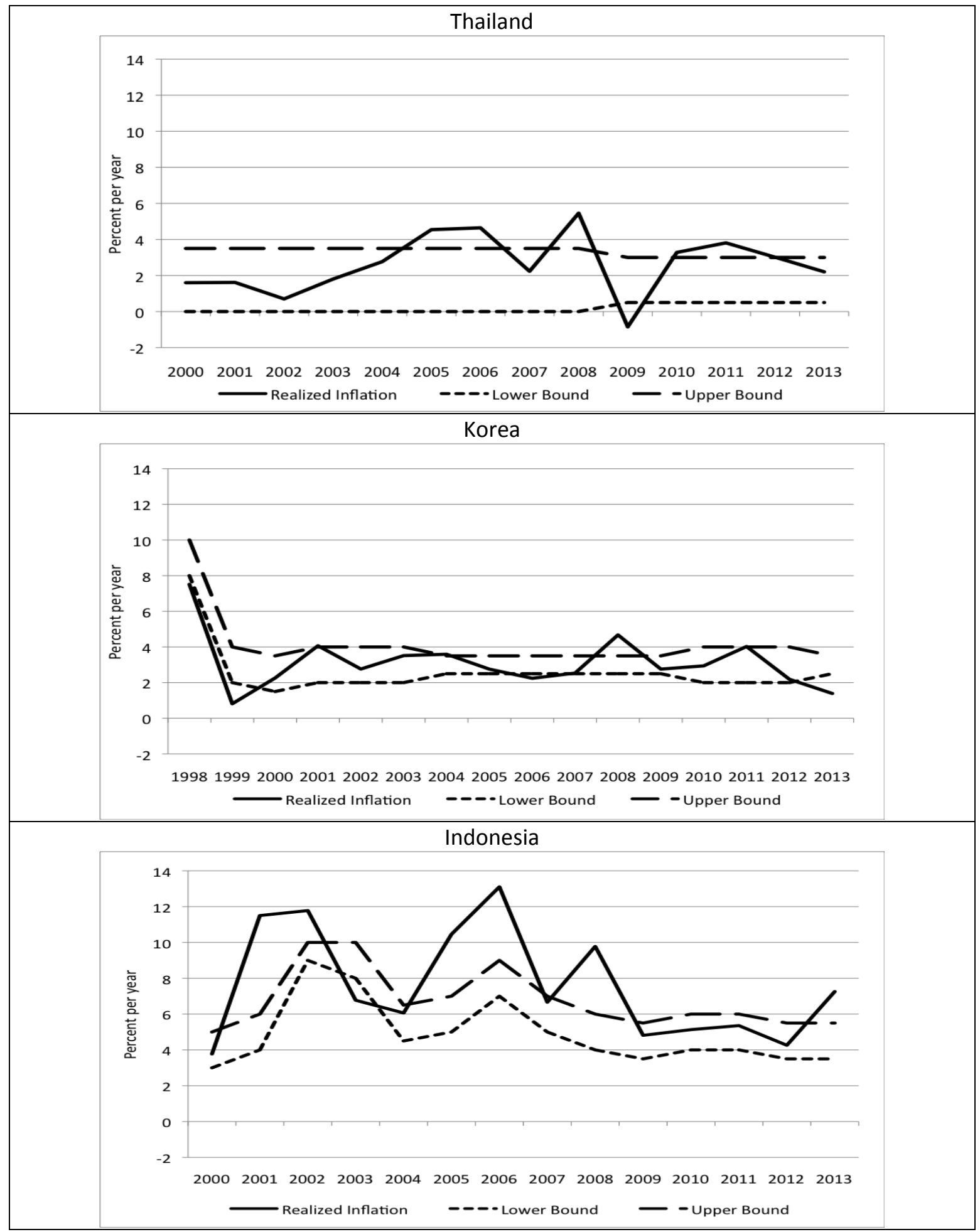

Sources: Year average CPI inflation from IMF, World Economic Outlook database, October 2013 (forecasts for 2013). Inflation targets are from the respective central banks. 
Figure 5: CPI Inflation Rates around Crises

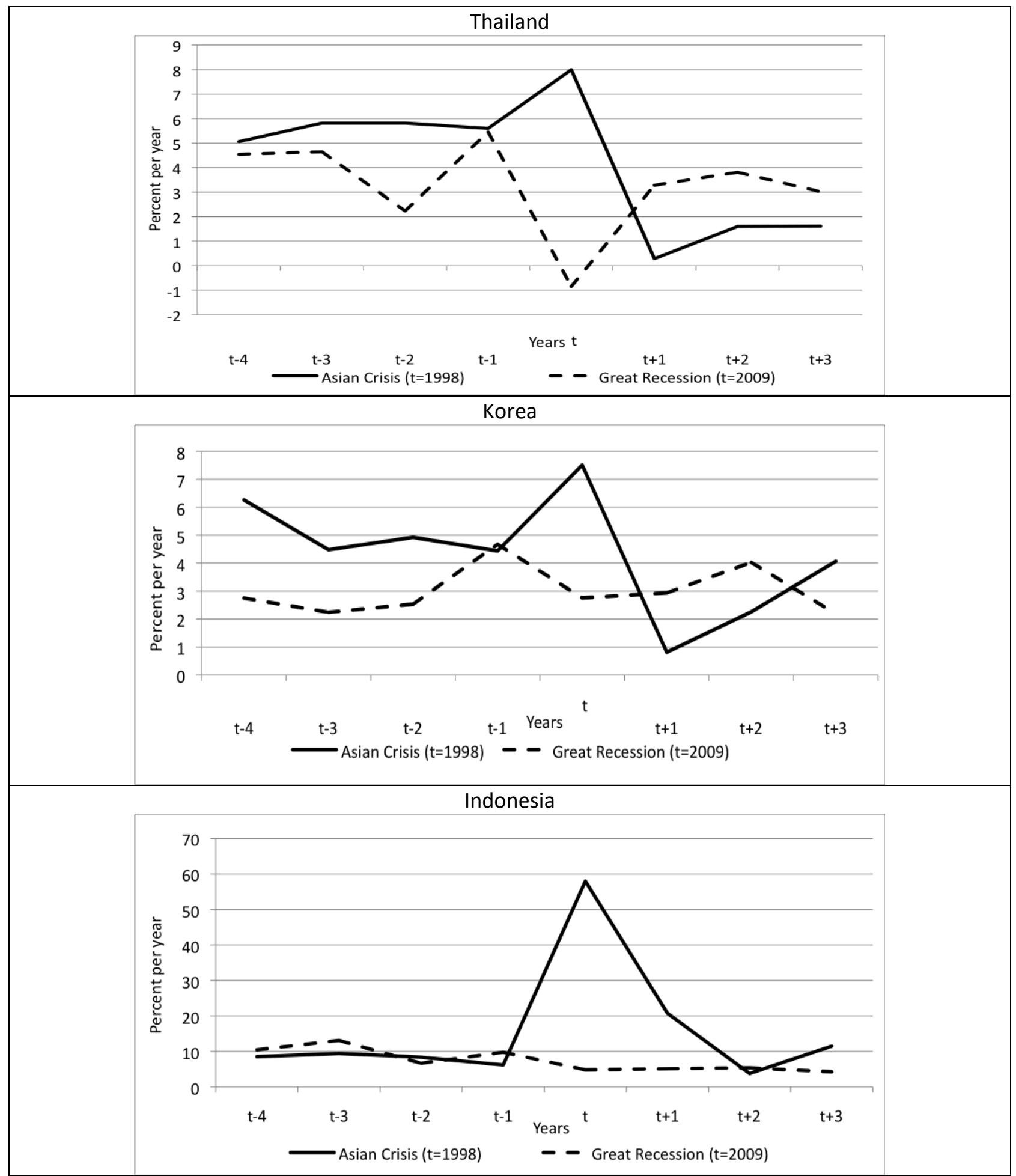

Source: Year average CPI inflation from the IMF, World Economic Outlook database, April 2013. 
Figure 6: Nominal Exchange Rates around Crises

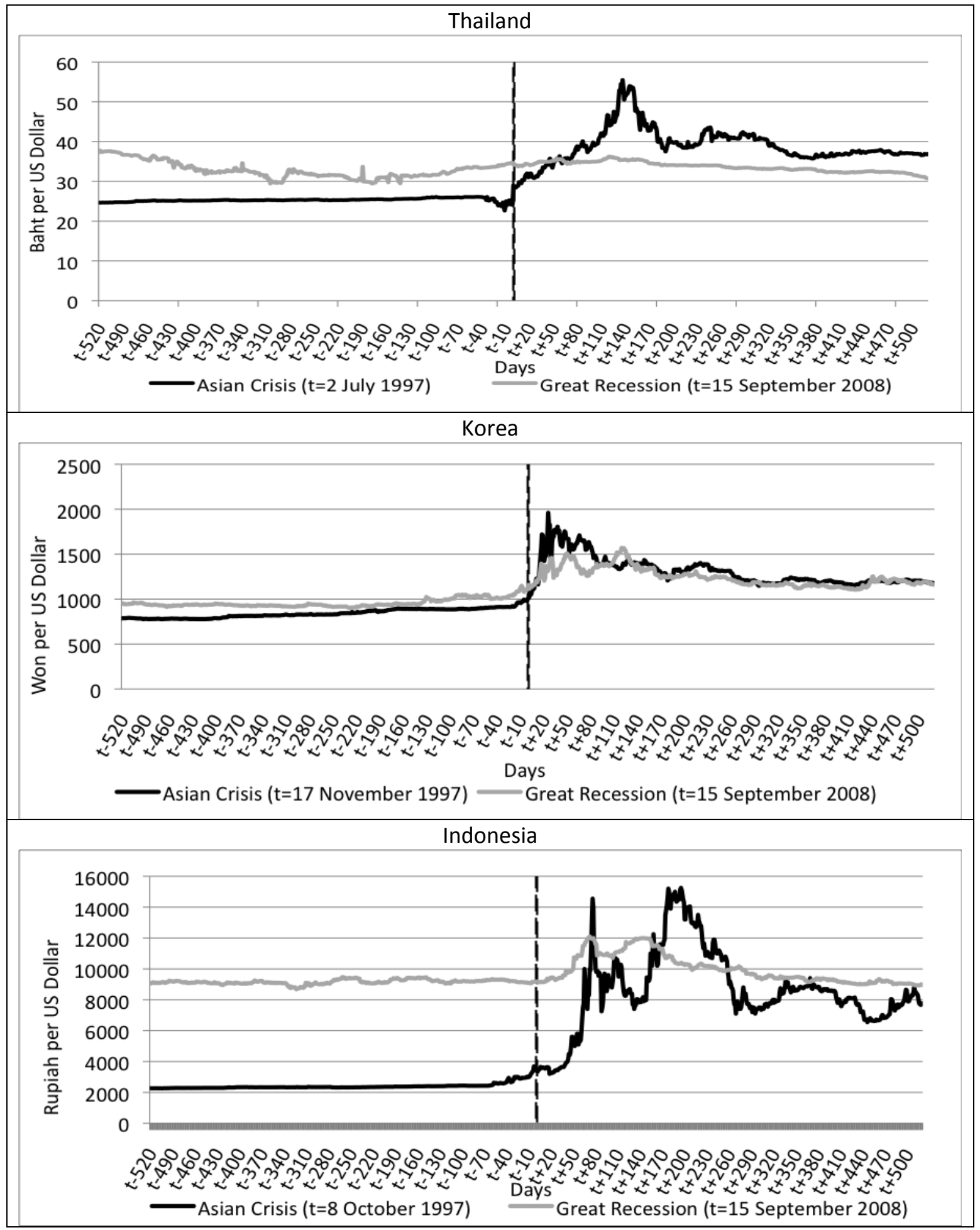

Source: Global Financial Data. 
Figure 7: Overnight Nominal Interest Rates around Crises

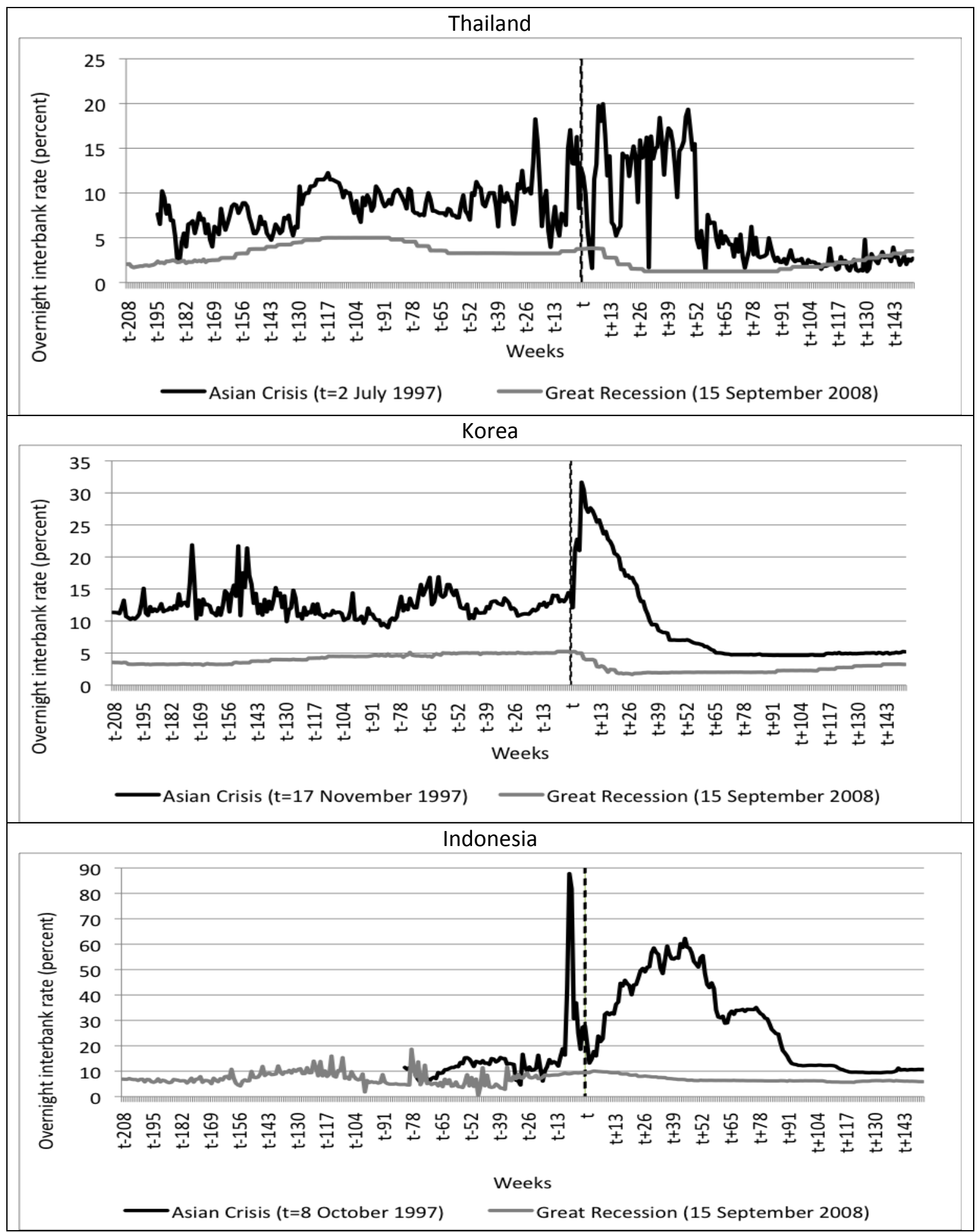

Source: Global Financial Data. 
Figure 8: Within-Month Nominal Exchange Rate Volatility

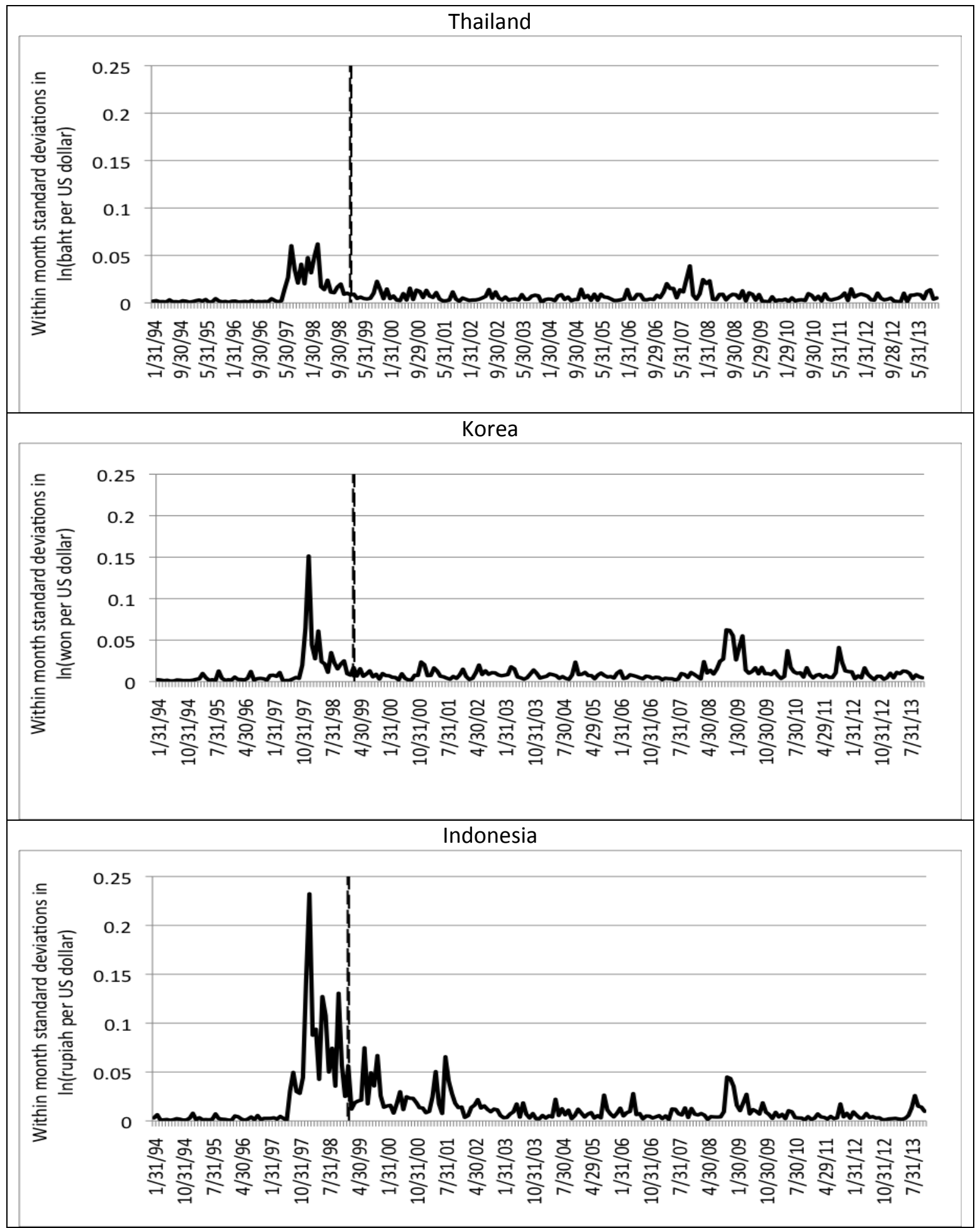

Source: Global Financial Data and author's calculations. 
Figure 9: Shekel U.S. Dollar Exchange Rate and Israel's Foreign Exchange Reserves

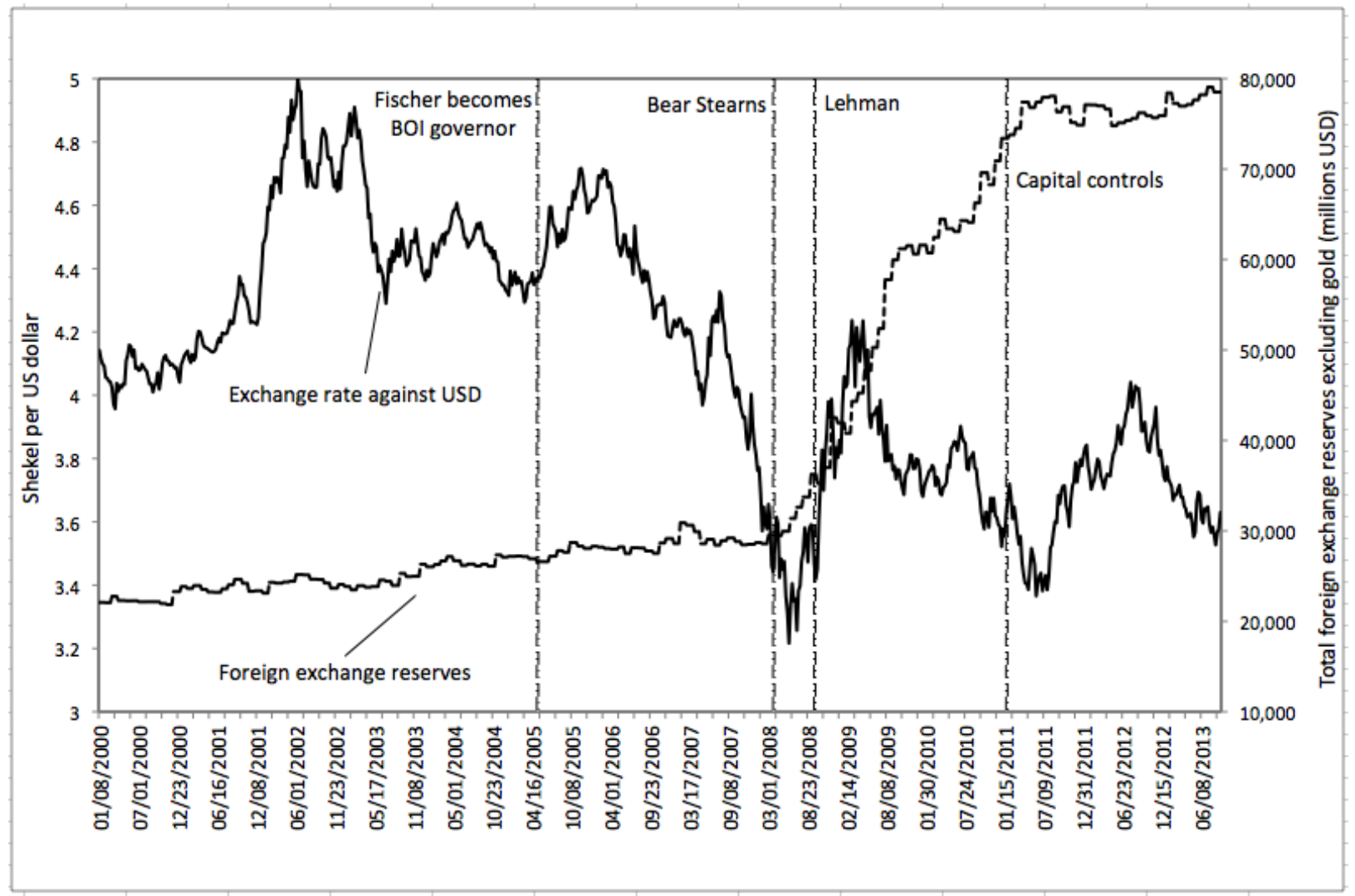

Source: Global Financial Data. 
Figure 10: Currency Shares in Global Foreign Exchange Turnover Compared to Issuing Countries' Shares in Global GDP

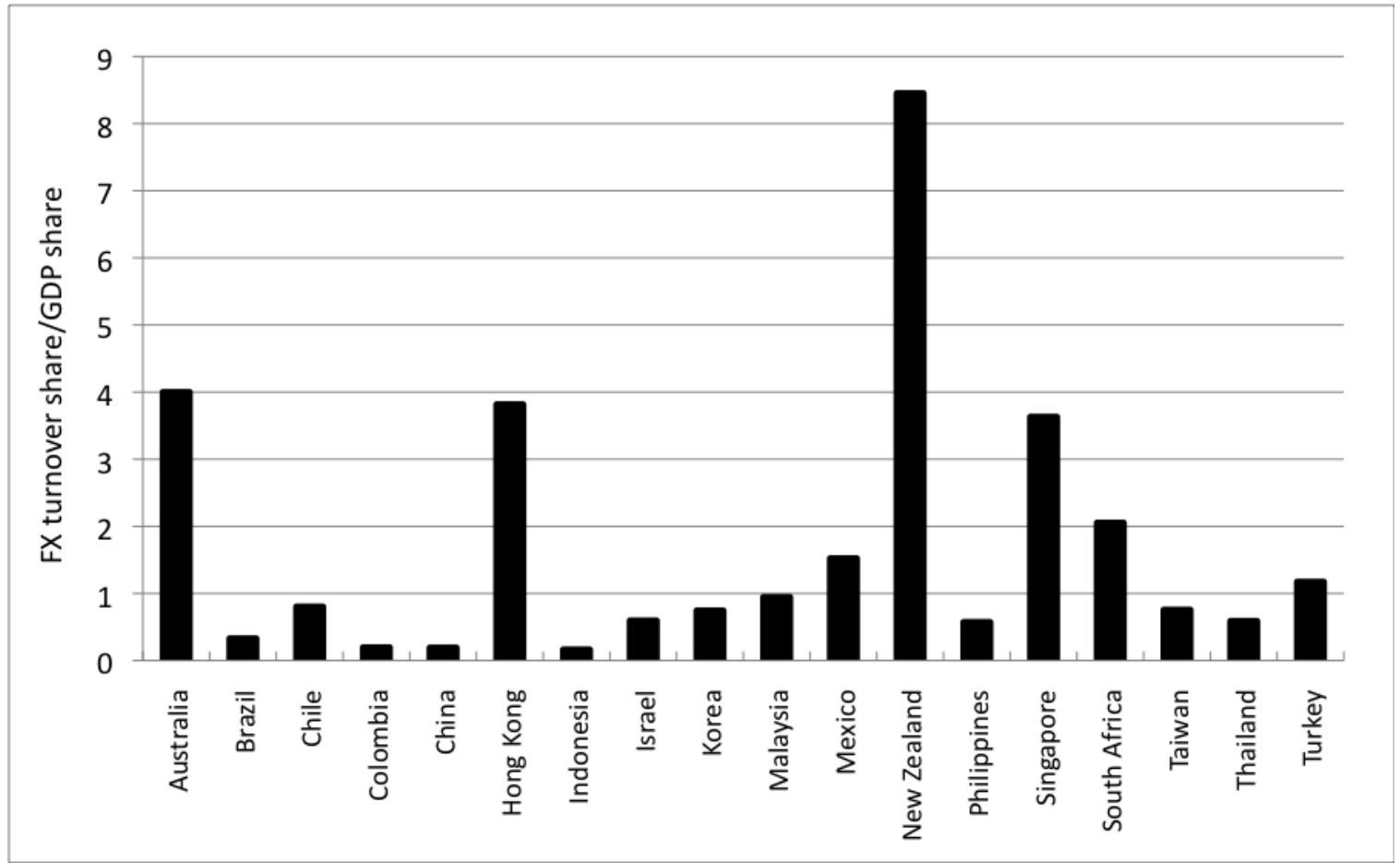

Sources: BIS triennial survey, preliminary 2013 results, and IMF, World Economic Outlook database, April 2013. 
Figure 11: Foreign Exchange Reserves (excluding gold) as a Percent of Gross Foreign Debt Liabilities around Crises

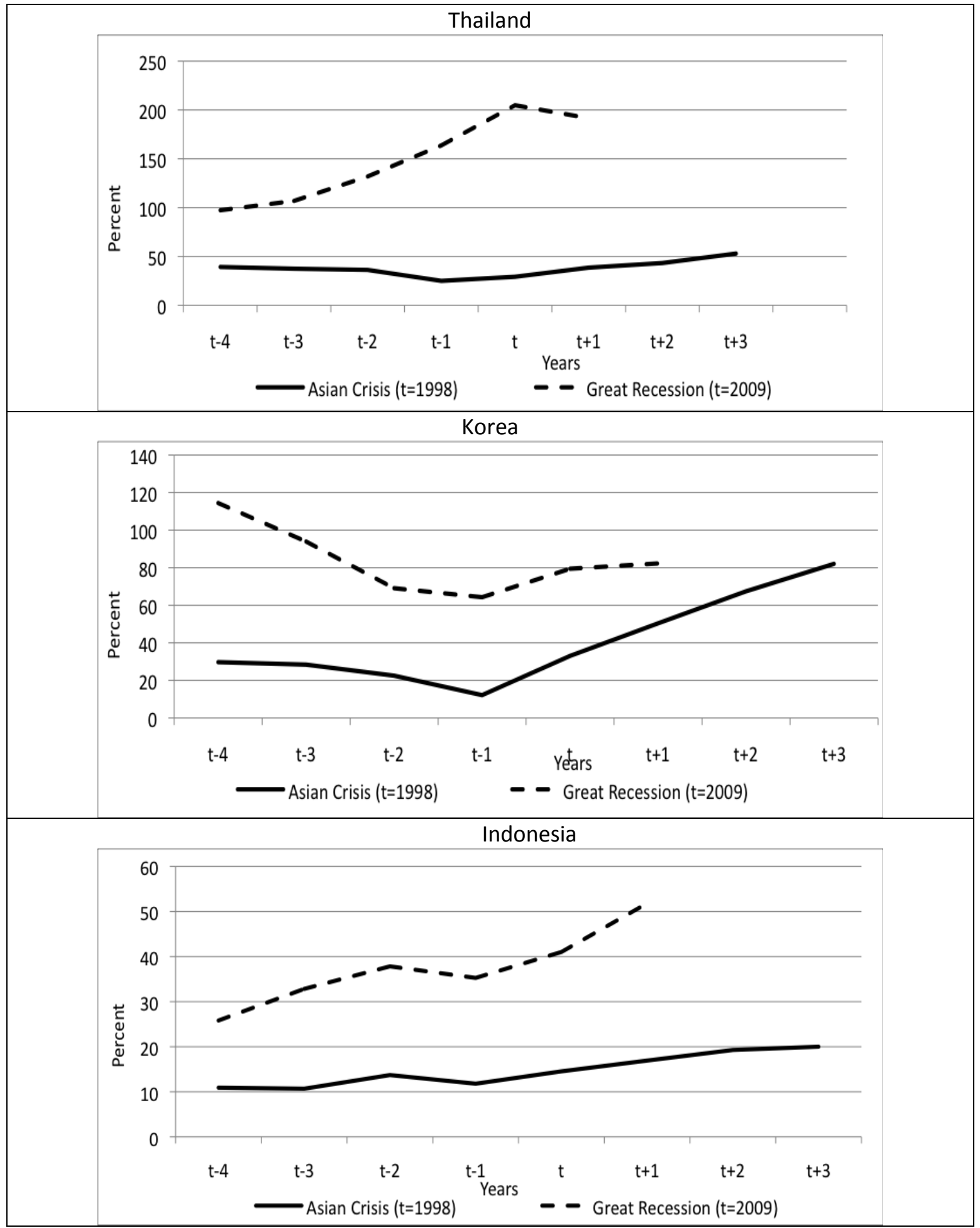

Source: Lane and Milesi-Ferretti, "The External Wealth of Nations Mark II," July 2013 Update. 
Figure 12: Public Debts in G-7 versus Emerging and Developing Economies (percent of GDP)

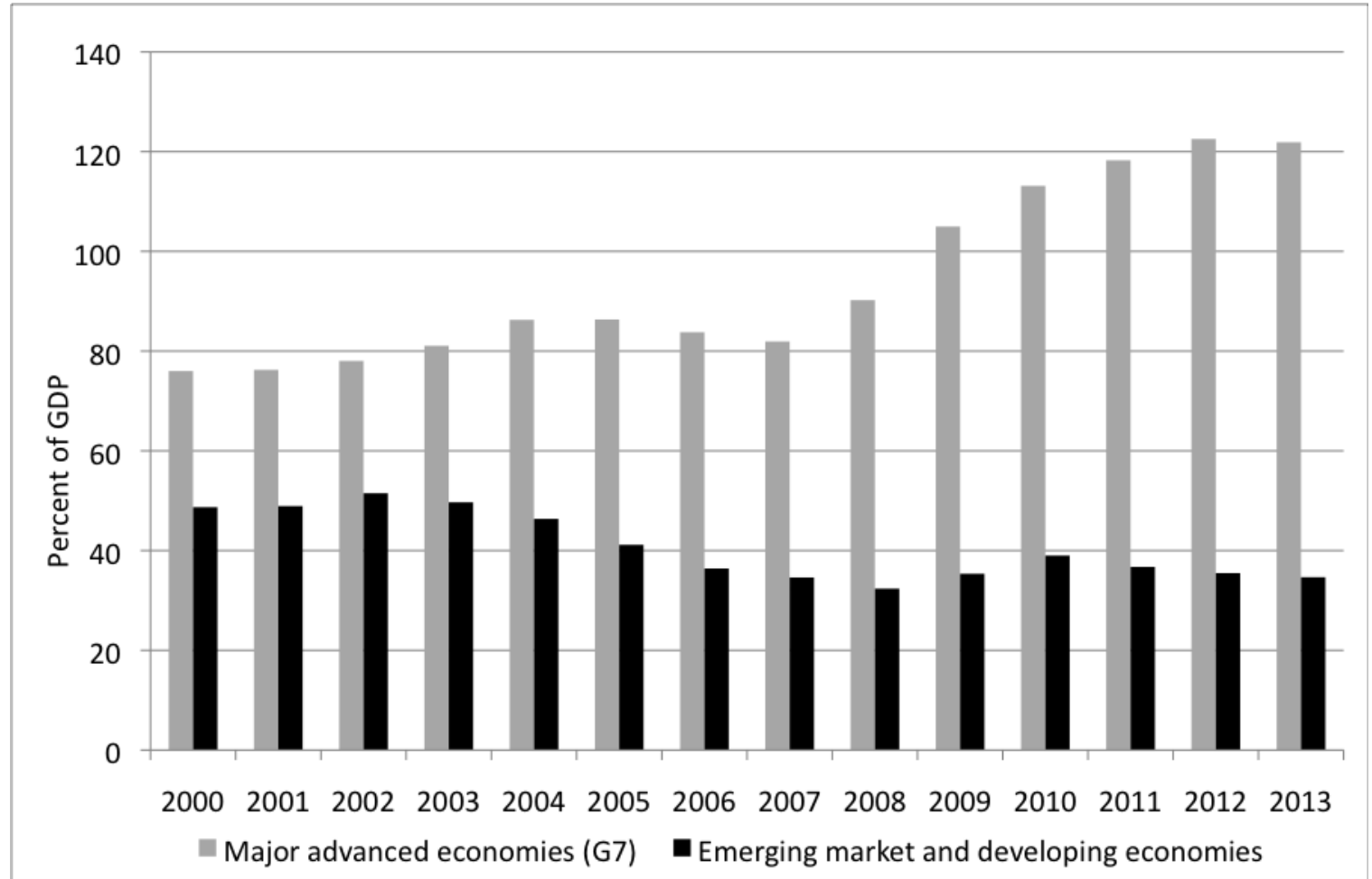

Source: IMF, World Economic Outlook database, October 2013 (forecasts after 2012). 
Figure 13: Gross Foreign Equity Liabilities as a Share of Total Gross Foreign Liabilities around Crises

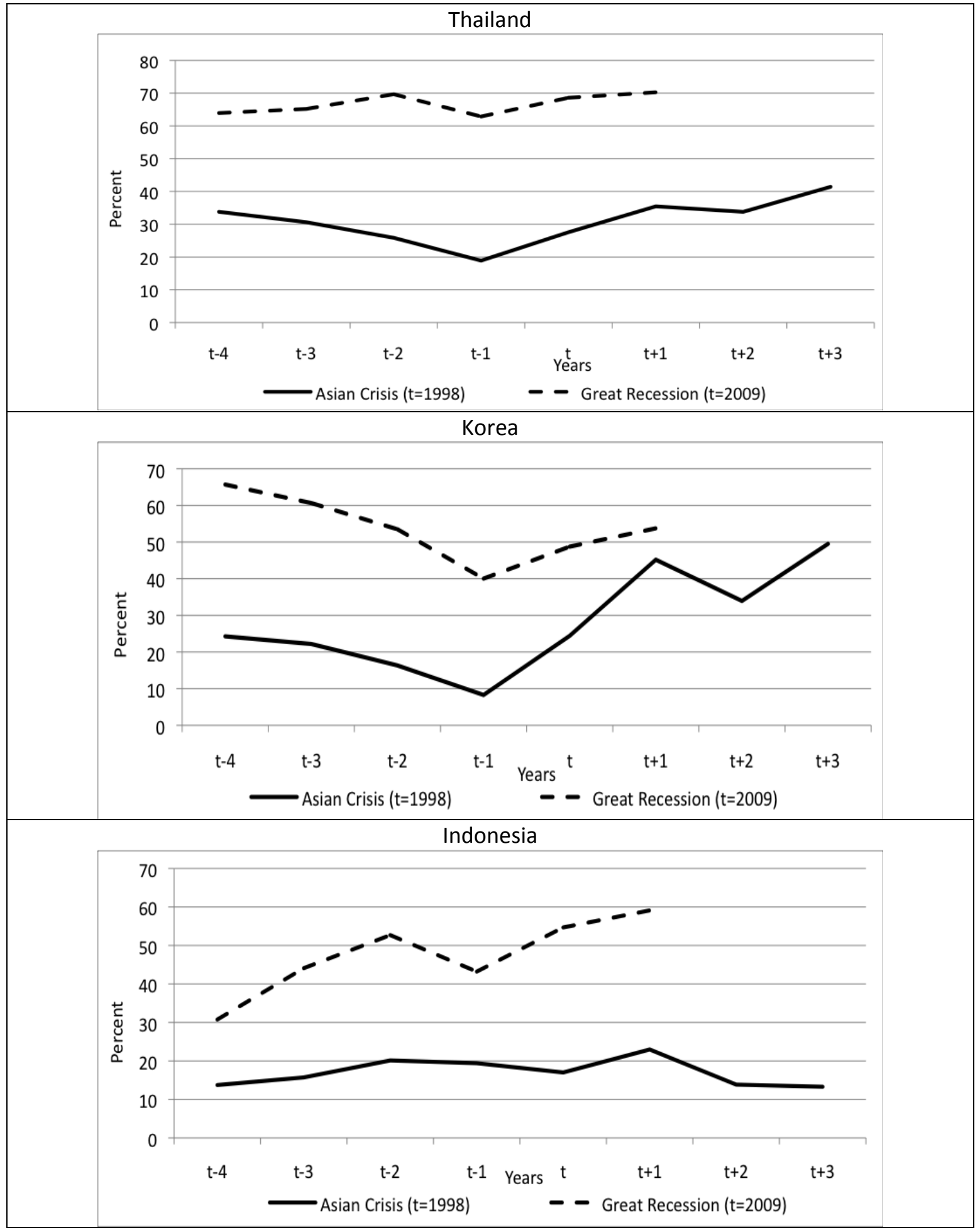

Source: Lane and Milesi-Ferretti, "The External Wealth of Nations Mark II," July 2013 Update. 
Figure 14: Domestic Credit from Banks as a Percent of GDP

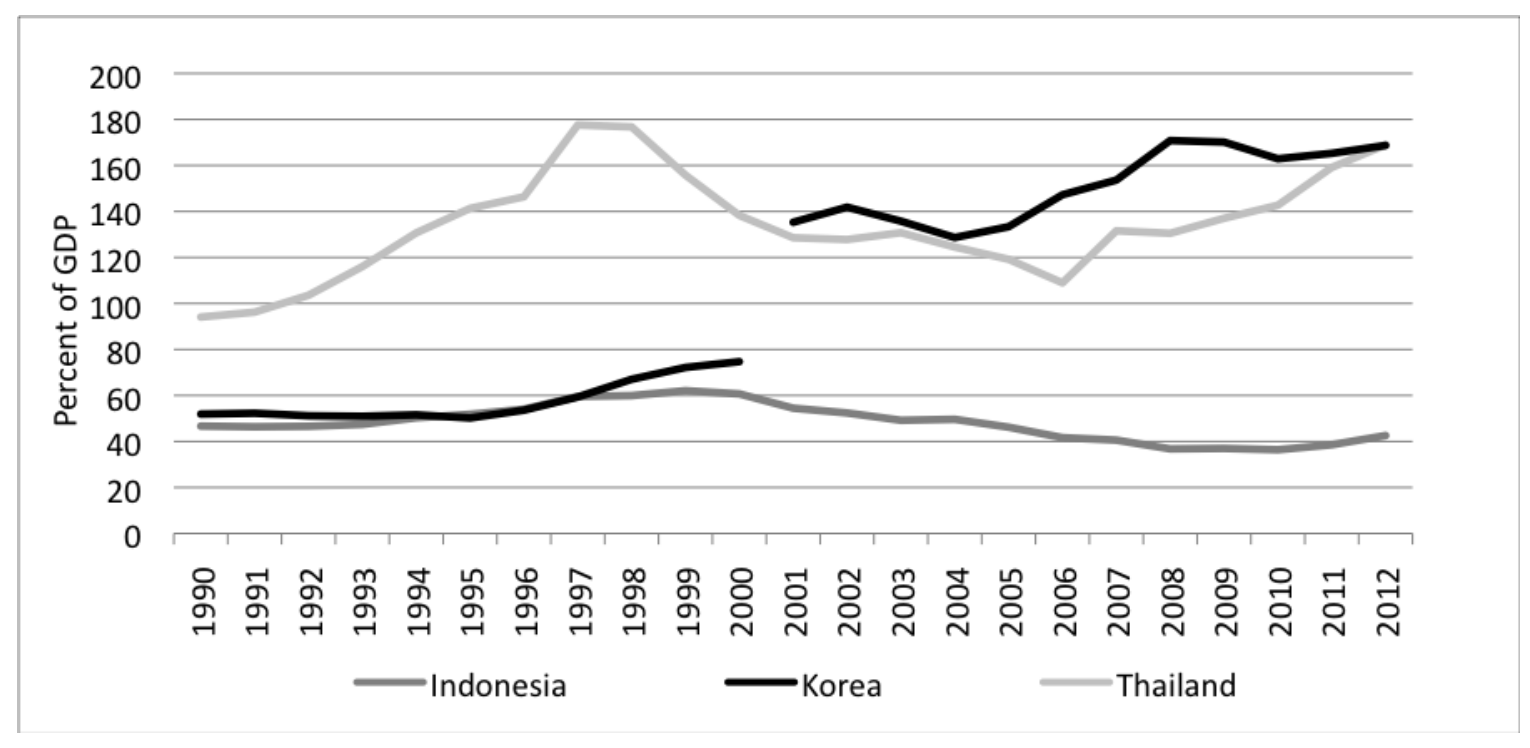

Source: World Bank, World Development Indicators. 